\title{
Shadow banking: a bibliometric and content analysis
}

\author{
Ridoy Deb Nath and Mohammad Ashraful Ferdous Chowdhury*
}

\section{*Correspondence: \\ ashraful_ferdous@yahoo. com; ashraf-ban@sust.edu Department of Business Administration, Shahjalal University of Science and Technology, Sylhet, Bangladesh}

This review article is based on the dissertation of Ridoy Deb Nath.

\begin{abstract}
This study reports on our systematic review of 2008-2021 literature on shadow banking. We present an overview of the shadow banking sector, wherein we discuss the definitions, evolution, functions, and specific activities that comprise it. We conducted a bibliometric analysis using the VOSviewer bibliometric tool on articles collected from the Scopus database, after which we conducted content analysis on top articles from leading sources, and identified four major streams of shadow banking literature. Additionally, we identified gaps in the literature and proposed seven research questions to be addressed in future studies to advance knowledge of the shadow banking sector. The findings of this review may serve as a robust reference for scholars researching various aspects of shadow banking to develop our understanding of this sector.
\end{abstract}

Keywords: Shadow banking, Review study, Bibliometric analysis, Content analysis, VOSviewer

\section{Introduction}

Shadow banking (SB) has been an essential and largely disputed issue in finance literature for over a decade. Its macroeconomic implications and institutional-level importance have made it a fascinating area of study for researchers and business professionals. After the Global Financial Crisis of 2007-2008 (GFC), scholars, legislators, and business professionals had SB in their sights. Many scholars have argued that the GFC initially sprouted from the SB sector, and that SB was the main culprit in the crisis (Gorton and Metrick 2010; Pozsar et al. 2010; Ashcraft and Adrian 2012; Acharya et al. 2013; Ban and Gabor 2016). The SB sector's vulnerability was in its financing of risky, long-term, and illiquid assets with short-term borrowings, resulting in a breakdown in the credit market that forced SBs to sell long-term holdings at fire-sale prices (Geithner 2008). However, some studies argue that SBs were not entirely responsible for the sub-prime mortgage crisis during the GFC. Moreover, SBs may be a key to mitigating damages if a liquidity crisis caused by traditional banks arises in the future (e.g., Wallison 2012; Culp 2013; Culp and Neves 2017). There is also evidence that the SB system provides commercial banks with sources for increased loanable funds and assumes some of the risks associated with loan origination (Culp and Neves 2017). As the future of SB and the new financial innovations within the SB sector hangs in the balance, some suggest taming the

(c) The Author(s), 2021. Open Access This article is licensed under a Creative Commons Attribution 4.0 International License, which permits use, sharing, adaptation, distribution and reproduction in any medium or format, as long as you give appropriate credit to the original author(s) and the source, provide a link to the Creative Commons licence, and indicate if changes were made. The images or other third party material in this article are included in the article's Creative Commons licence, unless indicated otherwise in a credit line to the material. If material is not included in the article's Creative Commons licence and your intended use is not permitted by statutory regulation or exceeds the permitted use, you will need to obtain permission directly from the copyright holder. To view a copy of this licence, visit http:// creativecommons.org/licenses/by/4.0/. 
wild horse, and others suggest letting it roam free. To that point, Wallison (2012) argued that the diverse financial innovation that is SB could be regulated away, leaving us with boring banking. On the other hand, some say that if SB remains unregulated or is regulated differently than the traditional banking sector, it will bring about the next global financial crisis (e.g., Moosa 2017). Clearly, proponents and detractors of SB have much to debate in the literature.

Our intention was to capture the diversity of positions and arguments in literature on SB. Accordingly, our main objectives were to examine the structure and development of SB research, explore the major research streams, and summarize the current state of knowledge in the field. Furthermore, we present inconsistencies in prior studies and possible explanations for them. Finally, we identify gaps in the SB literature and address needs for future research. We conducted bibliometric and content analysis on the SB articles we collected. The bibliometric analysis revealed the popular most keywords and the most influential studies, authors, and sources, along with various other aspects of SB research. Our content analysis identified four distinct research streams in SB literature, and we present important arguments from each such stream. That is, we first systematically analyzed the relevant literature retrieved from the Scopus database in our bibliometric analysis, and then, in our content analysis, we reviewed the most necessary and pertinent documents, as identified in the bibliographic analysis. This study contributes to SB literature because few review studies on SB literature exist. This review is unique in that it presents both bibliometric and content analysis of SB research from 2008 to 2021, and it further contributes to the field by identifying seven research questions that should be addressed in future studies on SB.

The remainder of the essay advances as follows: in "An overview of SB" section, we present a general review and the definitions, evolution, and functions of the SB sector, followed by a description of the study's "Methodological approach" in second section and the "Bibliometric analysis" findings in third section. In fifth section, we present "Content analysis", describe each of the research streams, and summarize the articles most critical to each stream. Section "Content analysis" also features the seven future research questions and a thorough guide to them. Finally, in "Conclusion" section, we conclude with thoughts on the SB sector and further research opportunities in the SB literature.

\section{An overview of SB}

\section{Definitions of SB}

The term "shadow banking" was coined by PIMCO's Paul McCulley, an economist and money manager, at an economic symposium arranged by the Federal Reserve Bank of Kansas City in Jackson Hole, Wyoming in 2007 (McCulley 2007). McCulley (2007) defined the SB system as "the whole alphabet soup of levered up non-bank investment conduits, vehicles, and structures." Pozsar et al. (2010) defined SBs as "financial intermediaries that conduct maturity, credit and liquidity transformation without access to central liquidity or public sector credit guarantees." As Noeth and Sengupta (2011) noted, the meaning of the SB banking system and its scope are widely debated in SB literature. Even the Financial Stability Board (FSB), an international body, defines the SB system from both broad and narrow perspectives. The FSB's broad definition of SB is "credit intermediation involving entities and activities outside the regular banking system" (FSB 


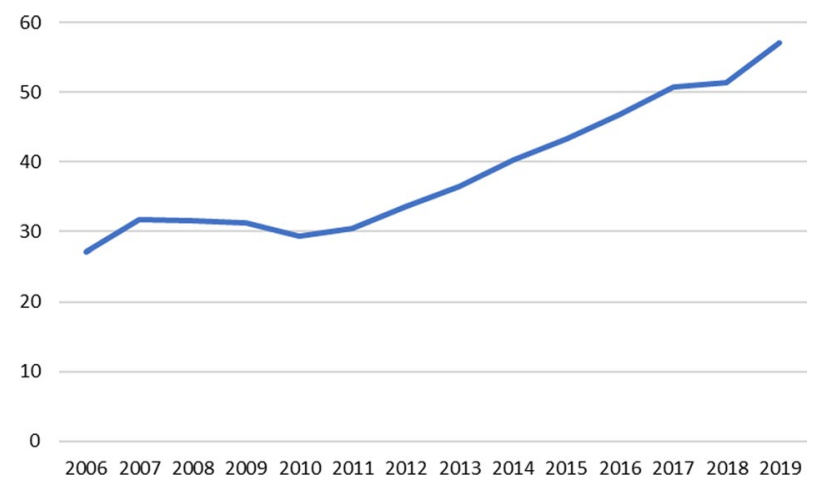

Fig. 1 Shadow banking assets in the World (USD trillion). Source: FSB (2020)

2011a). The FSB's (2011a) narrow definition of SB is “(1) developments that increase systemic risk (in particular maturity/liquidity transformation, imperfect credit risk transfer and/or leverage), and/or (2) indications of regulatory arbitrage that is undermining the benefits of financial regulation." This broad definition has been narrowed to target specific types of entities and activities.

According to Ağırman et al. (2013), SBs are a "wide myriad of highly leveraged nondeposit-taking institutions that lend long and borrow short in liquid markets." Kodres (2013) characterized SB entities by "a lack of disclosure and information about the value of their assets (or sometimes even what the assets were); opaque governance and ownership structures between banks and shadow banks; little regulatory or supervisory oversight of the type associated with traditional banks; virtually no loss-absorbing capital or cash for redemptions; and a lack of access to formal liquidity support to help prevent fire sales." The Economist (2014) put it more simply, arguing that SB should include "any bank-like activity undertaken by a firm not regulated as a bank." Thus, we can observe the development of definitions and perspectives on SB alongside the evolution of the actors participating in SB over the last 14 years. Ultimately, as Pozsar (2018) argued, what $\mathrm{SB}$ is and which actors are involved in it may vary depending on whom we ask.

\section{Evolution of SB}

According to McCulley (2007), the SB system originated with the birth of Money Market Mutual Funds (MMMFs) in the 1970s. Some authors also reported the "emergence of an unregulated parallel banking system" (presumably SB) in the early 1990s (D'Arista and Schlesinger 1993). Gorton and Metrick (2010) attributed the development of the SB system to the regulatory and juridical changes that indulged three types of institutions: "MMMFs to capture retail deposits from traditional banks, securitization to move assets of traditional banks off their balance sheets, and repurchase agreements (repos) that facilitated the use of securitized bonds as money." Others are of the view the SB system originated to fill a gap in the economic system (Landau 2019).

Whatever the case, the size of SB has increased rapidly since the GFC. For instance, FSB (2020) reveals that the narrow measure of SB assets increased by $11.1 \%$ to 57.1 trillion (USD) in 2019 from the previous year, representing 14.2\% of total global financial assets. Figure 1 depicts the growth of shadow banking assets (narrow measure) from 2006 to 2018. 


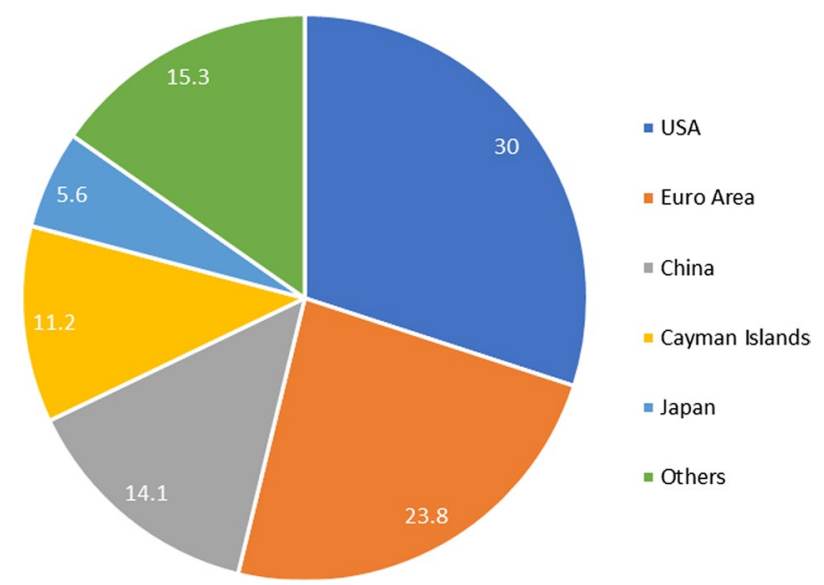

Fig. 2 Share of shadow banking assets by region (\%). Source: FSB (2020)

Additionally, the FSB report reveals the global share of SB assets (narrow measure) by the 29 jurisdictions it monitors. Figure 2 depicts the percentage of SB assets in 2019 by the 29 jurisdictions.

Here, the Euro Area includes Belgium, France, Germany, Ireland, Italy, Luxembourg, Netherlands, and Spain. Other areas include the other FSB 29-group countries.

\section{Functions and activities of SB}

SBs execute credit intermediation functions between investors and borrowers and generate income in this process from the difference in interest rates or fees. However, SBs are not subject to a similar level of regulatory requirements as traditional banks (Moosa 2017). Accordingly, Gorton and Metrick's (2010) argued that "fundamental changes in the financial system in the last 30-40 years, as a result of private innovation and regulatory changes, together led to the decline of the traditional banking model." They further argued that as traditional banks encountered severe competition from the non-bank financial institutions sector, they too sought new profit opportunities in the shadows.

As noted above, the FSB defines SB narrowly and broadly when measuring its scope. The broad measure comprises the non-bank financial intermediation (NBFI) sector and is also known as the Monitoring Universe of Non-bank Financial Intermediaries (MUNFI) (FSB 2019). MUNFI encompasses all financial institutions that are not banks, central banks, or other public financial institutions. Thus, the FSB's broad measure of SB includes pension funds, insurance companies, and other financial institutions (OFIs). The OFI subset includes finance companies, investment funds, trust companies, captive financial institutions and money lenders (CFIMLs), structured finance vehicles, and the like.

The FSB's narrow definition of SB (presented in Table 1 with examples) is based on economic functions. 
Table 1 FSB's narrow definition of shadow banking and example of classified entity type

\begin{tabular}{|c|c|c|}
\hline Economic functions & Definition & Typical entities \\
\hline Economic-function: 1 & $\begin{array}{l}\text { Management of collective investment } \\
\text { vehicles with features that make them } \\
\text { susceptible to runs }\end{array}$ & $\begin{array}{l}\text { MMFs, fixed-income funds, mixed funds, } \\
\text { credit hedge funds, real estate funds }\end{array}$ \\
\hline Economic-function: 2 & $\begin{array}{l}\text { A loan provision that is dependent on } \\
\text { short-term funding }\end{array}$ & $\begin{array}{l}\text { Finance companies, leasing/factoring com- } \\
\text { panies, consumer credit companies }\end{array}$ \\
\hline Economic-function: 3 & $\begin{array}{l}\text { Intermediation of market activities that } \\
\text { is dependent on short-term funding or } \\
\text { secured funding of client assets }\end{array}$ & Broker-dealers, securities finance companies \\
\hline Economic-function: 4 & Facilitation of credit creation & $\begin{array}{l}\text { Credit insurance companies, financial guar- } \\
\text { antors, monoline }\end{array}$ \\
\hline Economic-function: 5 & $\begin{array}{l}\text { Securitization-based credit intermediation } \\
\text { and funding of financial entities }\end{array}$ & $\begin{array}{l}\text { Securitization vehicles, structured finance } \\
\text { vehicles, asset-backed securities }\end{array}$ \\
\hline
\end{tabular}

Source: FSB (2020)

Some traditional banking areas are strongly interconnected with SB entities. Traditional banks engage in SB activities through off-balance-sheet accounts (e.g., Tian et al. 2016; An and Yu 2018; Tymoigne and Wray 2013) by supplying credit money to enterprises using non-standard accounting measures that bypass regulatory constraints (Sun 2019). "Shadow or money creation by banks beyond traditional loans" has two main components: (1) assets channeled by other traditional banks (e.g., reverse repo of bills, dual buyout of credit assets, interbank payments, etc.) and (2) activities channeled by non-bank financial intermediaries (e.g., credit swaps, trust beneficial interests, asset management plans, etc.) (Sun 2019). Although SB lending is similar to traditional bank lending, shadow loans are not listed as loans on the balance sheet. Such activity is often listed as interbank assets, investment assets, or off-balance sheet items. FSB (2011b) states that traditional banks extend financial support to the SB sector by granting loans, investing in SB products, or involving themselves in the SB intermediation process. Banks can also own finance companies and other SB entities (FSB 2012).

\section{Methodological approach}

Our approach to reviewing SB literature combined bibliometric analysis and content analysis. The bibliometric analysis method has been frequently adopted in literature review studies (e.g., Iddy and Alon 2019; Naatu and Alon 2019; Bahoo et al. 2019; White et al. 2016). The content analysis method is widely used in business and finance literature (e.g., Zha et al. 2020; Paul and Rosado-Serrano 2019; Paul and Benito 2018; Paul and Singh 2017). The same combined methods approach was previously adopted by Bahoo et al. (2020a, b).

The literature review process used in this study is depicted in Fig. 3. We conducted the review in three stages. In the first stage, we collected 419 articles returned from the search term "shadow banking" from the SCOPUS database, chosen because it is the largest database of peer-reviewed literature (Zhang et al. 2020; Chadegani et al. 2013). We customized the SCOPUS Excel file, and, after screening the articles based on title and relevance, found 185 articles in the SB branch of financial literature. To ensure that no critical articles were 


\section{Step 1: Seletion of \\ Database \\ Step 2: Article Search \\ Through Keywords \\ Step 3: Exclusion of \\ Irrelevant Articles}
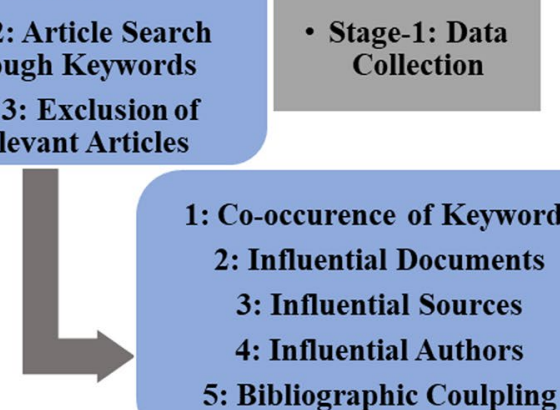

1: Co-occurence of Keywords

2: Influential Documents

3: Influential Sources

4: Influential Authors

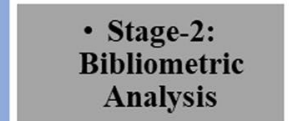

5: Bibliographic Coulpling

Analysis

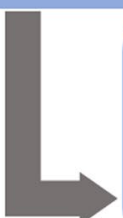

1. Identification of Research Streams

2. Presentation of Impactful Perspectives

3. Discussion of Future

Research Questions

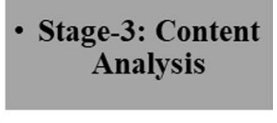

Fig. 3 Workflow of the literature review process

skipped, and to confirm that screened-out articles were, in fact, irrelevant to our research, we surfed the SCOPUS journals on finance manually.

The second stage of our review process was dedicated to bibliometric analysis of the 185 articles, using VOSviewer software. VOSviewer is a bibliometric analysis tool developed by Van Eck and Waltman (2010) to construct and view bibliometric maps. It can display such maps in multiple ways, each of which projects different aspects. This tool has been previously used by Donthu et al. (2020), Feng et al. (2020), Gutiérrez-Nieto and Serrano-Cinca (2019), Niñerola et al. (2019), Castillo-Vergara et al. (2018). We use it to analyze six aspects of SB literature. In the third stage of the review process, we conducted content analysis and manually identified four distinct research streams based on topical keywords and careful reading of abstracts. For additional specific details on the processes, which are, for purposes of clarity, covered along with the results, see the sections that follow.

\section{Bibliometric analysis}

\section{Bibliometric findings}

We analyzed the co-occurrence of all keywords used in the SB literature. We also examined the most highly cited documents, authors, and sources. Furthermore, we applied bibliographic coupling to determine shared sources between articles. The results of the bibliometric findings are presented in the following sections.

\section{Co-occurrence of keywords}

As the field of shadow banking literature is well-diversified, and there are some 372 of keywords frequently used in the literature over time, we filtered them by imputing five as the minimum number of occurrences of a keyword, and 14 of the 372 keywords met the threshold. 


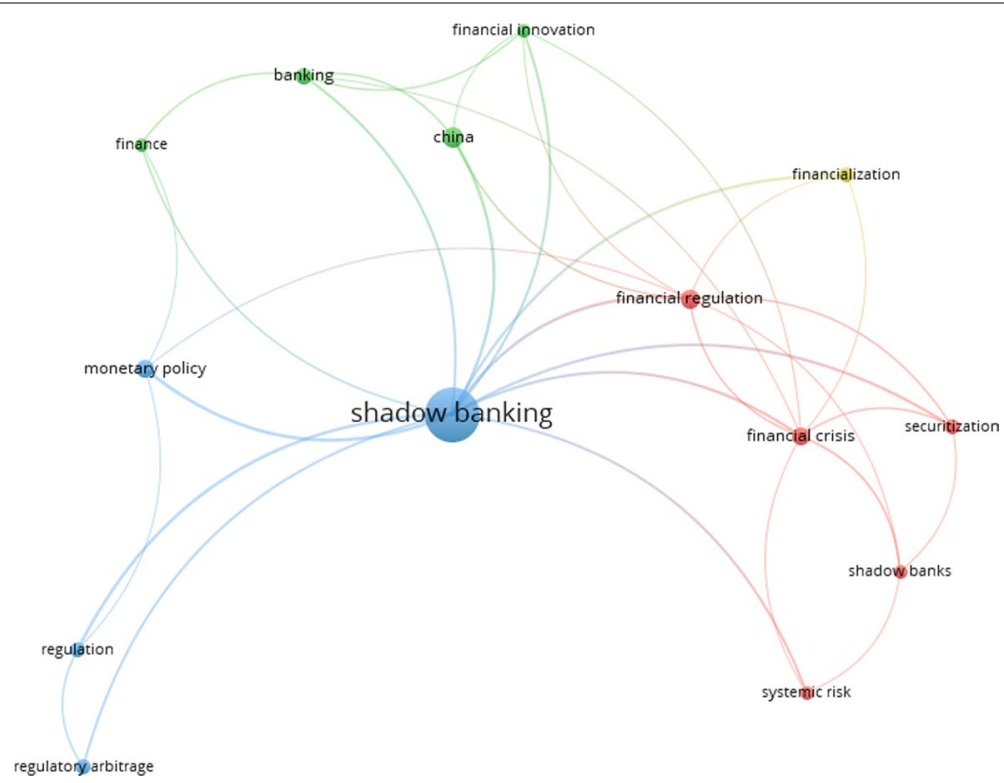

Fig. 4 Network map of co-occurrence of all keywords. Source: Authors' own estimation

Table 2 Highest cited documents on SB

\begin{tabular}{llll}
\hline References & $\begin{array}{l}\text { Number of } \\
\text { citations }\end{array}$ & References & $\begin{array}{l}\text { Number } \\
\text { of } \\
\text { citations }\end{array}$ \\
\hline Gorton and Metrick (2010) & 146 & Adrian and Shin (2010) & 24 \\
Gennaioli et al. (2013) & 85 & Acharya et al. (2013) & 22 \\
Adrian and Shin (2010) & 65 & Ban et al. (2016) & 22 \\
Rixen (2013) & 48 & Bengtsson (2013) & 21 \\
Plantin (2015) & 37 & Li (2014) & 19 \\
Chernenko and Sunderam (2014) & 36 & Gabor (2016) & 19 \\
Lu et al. (2015) & 35 & Nesvetailova (2015) & 19 \\
Lysandrou and Nesvetailova (2015) & 34 & Chen et al. (2018) & 17 \\
Sunderam (2015) & 31 & Kodres (2013) & 15 \\
Stein (2010) & 31 & Tsai (2015) & 15 \\
\hline
\end{tabular}

Source: Authors' own estimation

In Fig. 4, the node size represents the magnitude of the keyword's occurrence (Krauskopf 2018; van Eck and Waltman 2014). The figure thus indicates that the term "shadow banking" was the most frequently used of the 14 keywords identified. Other frequently used terms include "monetary policy," "China," "financial regulation," "regulation," "financial crisis," "shadow banks," "regulatory arbitrage," and "systemic risk." The results further revealed that the strongest link was between the terms "shadow banking" and "monetary policy." Additionally, "shadow banking" was found to have strong links with "regulation," "financial regulation," and "China." These findings suggest that the monetary policy and regulation of the financial system are the most common concerns regarding the $\mathrm{SB}$ sector. 


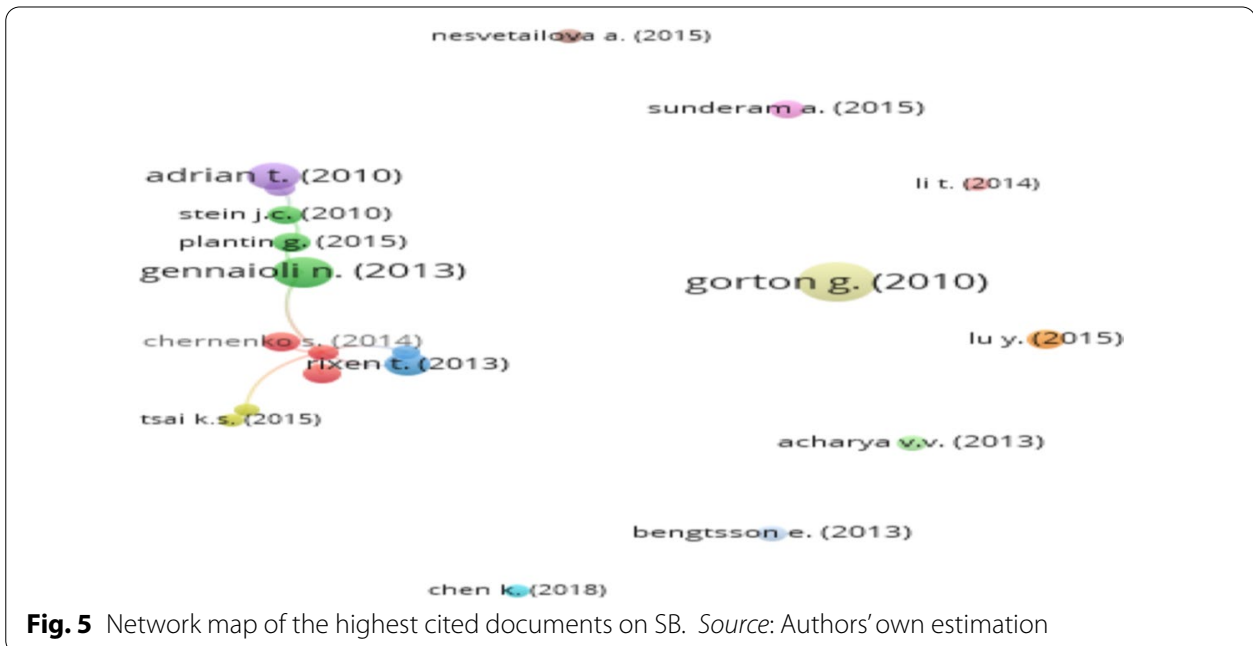

Table 3 Highest cited sources with corresponding number of documents

\begin{tabular}{lll}
\hline Source & Documents & Citations \\
\hline Brookings Papers on Economic Activity & 1 & 146 \\
Review of Financial Studies & 3 & 104 \\
Journal of Finance & 2 & 98 \\
Review of International Political Economy & 7 & 88 \\
Annual Review of Economics & 1 & 65 \\
International Review of Economics and Finance & 7 & 49 \\
Regulation and Governance & 1 & 48 \\
Journal of International Money and Finance & 3 & 43 \\
Daedalus & 1 & 31 \\
Annual Review of Financial Economics & 2 & 26 \\
Journal of Financial Economic Policy & 2 & 23 \\
New Political Economy & 2 & 22 \\
Journal of European Public Policy & 1 & 19 \\
American Economic Review & 1 & 17 \\
China Economic Review & 2 & 16 \\
\hline Source: Authors & &
\end{tabular}

Source: Authors' own estimation

\section{Most influential documents}

To determine the most highly cited documents in SB literature, we filtered the analysis to return documents that were cited a minimum of 15 times. Twenty of the 185 articles meet the threshold. Table 2 presents those 20 highest cited documents in SB literature.

Figure 5 presents the network map based on the most highly cited articles.

We found that a paper by Gorton and Metrick (2010) is the most highly cited document; however, it is not connected to the set of 12 interconnected articles as shown in Fig. 5. Similarly, Bengtsson (2013), Acharya et al. (2013), Li (2014), Lu et al. (2015), Nesvetailova (2015), Sunderam (2015), and Chen et al. (2018) are also absent in the connected set, despite being among the 20 most cited documents. 


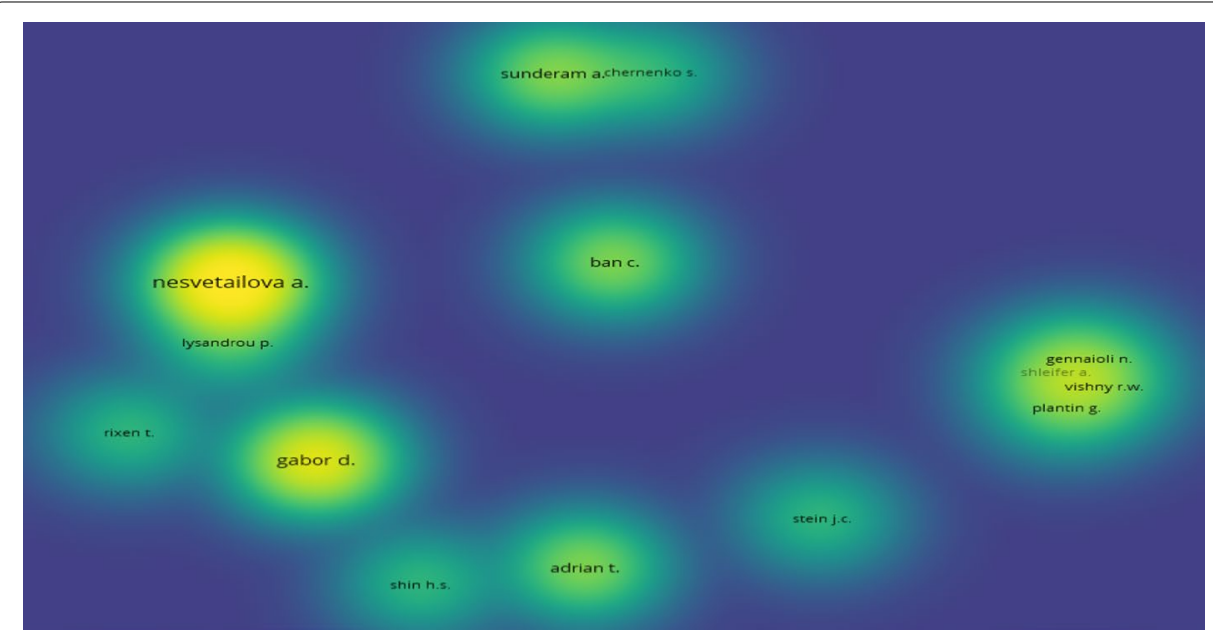

Fig. 6 Density visualization of authors with the highest number of documents. Source: Authors' own estimation

\section{Most influential sources}

This section reveals the most highly cited sources in the field of SB literature and the number of documents that rely on each such source. Here, to filter the sources, we selected one as the minimum number of documents for a source and 16 as the minimum number of citations to a source. After filtering, 15 of the 121 sources were returned. Table 3 presents a summary of those most influential sources.

\section{Most influential authors}

To identify the most influential authors in SB literature of shadow banking, we considered a maximum of 5 authors per document during the filtration process. Further, we used the minimum number of documents one and the minimum number of citations as 30 for filtration purposes. Twenty of the 284 authors met the threshold. Figure 6 presents a density visualization featuring the authors with the highest number of documents in the shadow banking literature.

Our findings suggest that Anastasia Nesvetailova published the most documents on SB, followed by Daniela Gabor. However, Gary Gorton and Andrew Metrick (146 citations each) were the most highly cited authors in the field. The following four authors are, as follows (documents, citations), Tobias Adrian $(2,89)$, Nicola Gennaioli $(1,85)$, Andrei Shleifer $(1,85)$, Robert W. Vishny $(1,85)$.

\section{Bibliographic document coupling}

The developers of VOSviewer suggest that bibliographic coupling results represent the overlap of references between publications. The greater the number of shared references between two papers, the greater the strength of the link between them. Here, we filtered the analysis by inputting the minimum number of citations of a document as 5 , resulting in 47 articles. However, only 44 articles were found in the connected set. Visualization of the bibliographic coupling of documents in the SB network is presented in Fig. 7. 


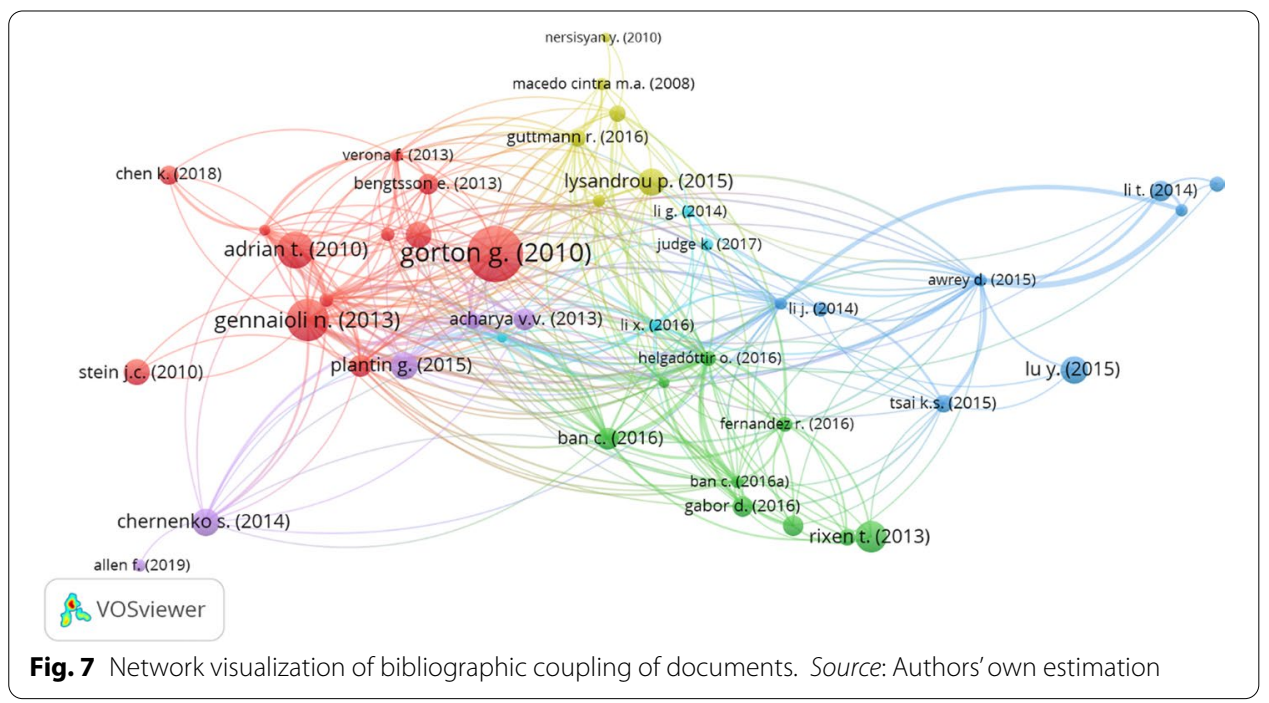

Helgadóttir (2016) was revealed as the document with the most significant total bibliographic coupling link strength (84 with 11 citations). The other top 5 articles ranked as follows. For each of the articles, the first number stands for total link strength and the second number for the number of citations. Moreira and Savov 2017) [75,13], Meeks et al. (2017) [72,9], Ban et al. (2016) [66,22], Awrey (2015) [66,7], Gennaioli et al. (2013) [66,85].

\section{Content analysis}

\section{Major research streams}

During content analysis, we analyzed the documents based on their relevance to our discussion and ensured that no critical document was skipped in the discussion. We identified four major research streams in SB literature using the topical keywords identified in the prior studies and found in the abstracts of the subject studies. Categorizing the research streams assists in visualizing the dimensions of SB that have been studied over the course of its evolution. However, we acknowledge that some articles belong to multiple streams because of the multidisciplinary nature of SB studies. Summaries of the main arguments in each stream are presented in Tables 4, 5,6 , and 7. Description of the articles and their findings are presented in the following four sections.

\section{Determinants of SB}

A limited number of studies have addressed the determinants of SB during the study period. However, the unique nature of these articles requires categorizing them separately within a distinct research stream.

Several older studies explained the process by which regulatory requirements, such as reserve requirements, give rise to alternatives to bank loans (e.g., Kanatas and Greenbaum 1982; Bernanke and Lown 1991; Duca 1992; Berger and Udell 1994) and to securitization (Pennacchi 1988). Other studies have also noted that changes in information 
Table 4 Key literature on determinants of SB

\begin{tabular}{|c|c|c|c|}
\hline References & Journal/conference & Country/region & Main arguments/findings \\
\hline $\begin{array}{l}\text { Apostoaie and Bilan } \\
(2020)\end{array}$ & $\begin{array}{l}\text { Economic Research- } \\
\text { Ekonomska Istraživanja }\end{array}$ & $\begin{array}{l}\text { Central and Eastern Euro- } \\
\text { pean countries }\end{array}$ & $\begin{array}{l}\text { Economic growth and } \\
\text { institutional investor's } \\
\text { higher funding demand } \\
\text { positively affect the devel- } \\
\text { opment of the shadow } \\
\text { banking sector. Addition- } \\
\text { ally, investors depend on } \\
\text { shadow banks for higher } \\
\text { yields in a low-interest } \\
\text { rate situation }\end{array}$ \\
\hline Barbu et al. (2016) & $\begin{array}{l}\text { Review of Economics and } \\
\text { Business Studies }\end{array}$ & 15 European countries & $\begin{array}{l}\text { Stock market indices and } \\
\text { the long-term interest } \\
\text { rates positively influence } \\
\text { the shadow banking size, } \\
\text { while the development of } \\
\text { investment funds and the } \\
\text { M2/GDP ratio negatively } \\
\text { impact }\end{array}$ \\
\hline Hodula et al. (2017) & $\begin{array}{l}\text { European Financial Sys- } \\
\text { tems } 2017\end{array}$ & Spain & $\begin{array}{l}\text { An increase in term spreads } \\
\text { and low interest rates } \\
\text { tend to affect the growth } \\
\text { of shadow banking } \\
\text { positively. Moreover, the } \\
\text { country-specific charac- } \\
\text { teristics and individual } \\
\text { components of shadow } \\
\text { banking have due impor- } \\
\text { tance in such studies }\end{array}$ \\
\hline Zhou and Tewari (2019a) & $\begin{array}{l}\text { Cogent Economics \& } \\
\text { Finance }\end{array}$ & $\begin{array}{l}14 \text { emerging economies } \\
\text { and Singapore }\end{array}$ & $\begin{array}{l}\text { A negative relationship } \\
\text { exists between shadow } \\
\text { banking and monetary } \\
\text { policy. Shadow banking } \\
\text { increases when bank risk- } \\
\text { taking is reduced }\end{array}$ \\
\hline Hodula et al. (2020) & Economic Systems & $24 \mathrm{EU}$ countries & $\begin{array}{l}\text { Difficile financial devel- } \\
\text { opment, strict regula- } \\
\text { tion, and demand for } \\
\text { long-term institutional } \\
\text { investors positively influ- } \\
\text { ence the shadow banking } \\
\text { growth }\end{array}$ \\
\hline $\operatorname{Kim}(2017)$ & $\begin{array}{l}\text { IFC Conference, Bank for } \\
\text { International Settle- } \\
\text { ments }\end{array}$ & G-20 Countries & $\begin{array}{l}\text { Insurance companies and } \\
\text { pension funds positively } \\
\text { influence shadow bank- } \\
\text { ing growth. The size of } \\
\text { banks'assets also reveals } \\
\text { similar results }\end{array}$ \\
\hline Duca (2016) & $\begin{array}{l}\text { Journal of Banking \& } \\
\text { Finance }\end{array}$ & USA & $\begin{array}{l}\text { Change in information } \\
\text { and reserve require- } \\
\text { ments costs and shift } \\
\text { in bank-nonbank credit } \\
\text { sources regulation has a } \\
\text { negative and long-run } \\
\text { impact on shadow banks' } \\
\text { share in funding short- } \\
\text { term business debt. This } \\
\text { share fell in the short run } \\
\text { when short-term liquidity } \\
\text { premia, term premia, and } \\
\text { event risks in the security } \\
\text { market increased }\end{array}$ \\
\hline
\end{tabular}


Table 5 Key literature on SB and systemic risk

\begin{tabular}{|c|c|c|c|}
\hline References & Journal/conference & Nature & Main arguments/findings \\
\hline Pellegrini et al. (2017) & Finance Research Letters & Empirical & $\begin{array}{l}\text { MMFs listed in the UK have decreased } \\
\text { systemic risk during GFC. Average } \\
\text { systemic risk is increased by liquidity } \\
\text { mismatch over the whole study } \\
\text { period, but the risk only decreases } \\
\text { during GFC }\end{array}$ \\
\hline Bengtsson (2016) & $\begin{array}{l}\text { Journal of Financial Regulation and } \\
\text { Compliance }\end{array}$ & Theoretical & $\begin{array}{l}\text { From the perspective of systemic } \\
\text { risk, hedge funds and conventional } \\
\text { investment funds have several } \\
\text { commonalities. Investment funds' } \\
\text { ability to substitute traditional } \\
\text { banks' maturity transformations may } \\
\text { be threatened by the instability in } \\
\text { funding profiles of the investment } \\
\text { funds }\end{array}$ \\
\hline Wymeersch (2017) & EBI Working Paper Series & Theoretical & $\begin{array}{l}\text { Banks have been bound to adapt the } \\
\text { behaviors, structure, and balance } \\
\text { sheet to the risk of participating in } \\
\text { the shadow banking market }\end{array}$ \\
\hline Hsu et al. (2013) & CITYPERC Working Paper Series & Theoretical & $\begin{array}{l}\text { Several factors, including herd behav- } \\
\text { ior, are creating systemic risk in the } \\
\text { European markets. Risk dispersion } \\
\text { across the underdeveloped seg- } \\
\text { ment of the shadow banking sector } \\
\text { has posed China some concen- } \\
\text { trated risks that have no contribu- } \\
\text { tion to the systemic risk }\end{array}$ \\
\hline Tian et al. (2016) & $\begin{array}{l}\text { Emerging Markets Finance and } \\
\text { Trade }\end{array}$ & Empirical & $\begin{array}{l}\text { Over the } 2007-2012 \text { period, trust } \\
\text { companies posed the most financial } \\
\text { Instability in China and this adverse } \\
\text { effect caused the commercial banks } \\
\text { the most }\end{array}$ \\
\hline Wei (2015) & Asia Pacific Law Review & Theoretical & $\begin{array}{l}\text { Regulators and the market players } \\
\text { object to shadow banks' exist- } \\
\text { ence as it generates financial risks. } \\
\text { However, commercial banks have } \\
\text { enjoyed a large amount of profit } \\
\text { generated by the WMPs. So, the } \\
\text { Chinese policymakers can formulate } \\
\text { a multi-tiered market for loans and } \\
\text { an interest rate environment to cure } \\
\text { WMPs'systemic risk }\end{array}$ \\
\hline Hsu et al. (2014) & PERI Working Paper Series & Empirical & $\begin{array}{l}\text { Trust companies pose the most } \\
\text { systemic risk in the Chinese shadow } \\
\text { banking system. The systemic risk } \\
\text { posed by banks, insurance com- } \\
\text { panies, and securities companies } \\
\text { had insignificant differences. Banks } \\
\text { absorbed the most systemic risks, } \\
\text { about } 85 \% \text {, in the shadow banking } \\
\text { system }\end{array}$ \\
\hline
\end{tabular}

costs contribute to the long-run rise of SB (e.g., Edwards and Mishkin 1995; Ratnovski 2013), although empirical assessment has been only rarely conducted. The first empirical study on determinants of SB was conducted by Barbu et al. (2016) and covered Austria, Belgium, Finland, France, Germany, Greece, Hungary, Italy, Latvia, Luxembourg, Norway, Romania, Slovenia, Spain, and Sweden. In that study, the dependent variable SB was proxied by the net value of the assets of monetary funds. The independent variables were the real GDP variation, interest rate level (both short-term and long-term), M2/GDP 
Table 6 Key literature on policy and political issues of SB

\begin{tabular}{|c|c|c|c|}
\hline References & Journal/conference & Nature & Main arguments/findings \\
\hline Yang et al. (2019) & Pacific-Basin Finance Journal & Empirical & $\begin{array}{l}\text { Shadow banking has a negative } \\
\text { influence on welfare at times of } \\
\text { monetary policy shock. Coordi- } \\
\text { nating leverage ratio regulations } \\
\text { and monetary policies would } \\
\text { help stabilize the financial system } \\
\text { and decrease the size of shadow } \\
\text { banking }\end{array}$ \\
\hline Zhang and Wan (2017) & $\begin{array}{l}\text { Emerging Markets Finance and } \\
\text { Trade }\end{array}$ & Empirical & $\begin{array}{l}\text { Chinese economic activities need } \\
\text { to be guided by a mix of policy } \\
\text { instruments. The transition from } \\
\text { quantitative policy tools to other } \\
\text { price-based instruments will not } \\
\text { be easy, but it will capture the } \\
\text { monetary policy stances to a little } \\
\text { extent, especially for the open } \\
\text { market operations }\end{array}$ \\
\hline Nesvetailova (2015) & New Political Economy & Theoretical & $\begin{array}{l}\text { Shadow banking results from regula- } \\
\text { tive arbitration in the traditional } \\
\text { banking system enhanced by the } \\
\text { nationwide accounting, taxation, } \\
\text { and banking rules. The administra- } \\
\text { tive arbitration approaches towards } \\
\text { shadow banking are useful but } \\
\text { limited }\end{array}$ \\
\hline Hou et al. (2018) & $\begin{array}{l}\text { International Review of Economics } \\
\text { and Finance }\end{array}$ & Empirical & $\begin{array}{l}\text { Political intervention negatively } \\
\text { impacts the bank cost efficiency, } \\
\text { which weakens the positive } \\
\text { relationship between bank cost } \\
\text { efficiency and shadow banking } \\
\text { growth }\end{array}$ \\
\hline Fève et al. (2019) & $\begin{array}{l}\text { Journal of Economic Dynamics \& } \\
\text { Control }\end{array}$ & Empirical & $\begin{array}{l}\text { As the macroprudential policies only } \\
\text { target the traditional banks and } \\
\text { the sector leakage reduces their } \\
\text { effectiveness, wider regulations } \\
\text { addressing shadow credit may help } \\
\text { stabilize the economy }\end{array}$ \\
\hline Bryan et al. (2016) & $\begin{array}{l}\text { Review of International Political } \\
\text { Economy }\end{array}$ & Theoretical & $\begin{array}{l}\text { The shadow banking sector is not } \\
\text { only a sector of erratic financial } \\
\text { practice and a reason for financial } \\
\text { fragility but also a sector of political } \\
\text { and juridical innovation }\end{array}$ \\
\hline Ban and Gabor (2016) & $\begin{array}{l}\text { Review of International Political } \\
\text { Economy }\end{array}$ & Theoretical & $\begin{array}{l}\text { Redistributing wealth on a large scale } \\
\text { is a better solution to redress the } \\
\text { economic structural imbalance } \\
\text { than better regulations of shadow } \\
\text { banks. Thus, the responsibility } \\
\text { is mostly on the influencers of } \\
\text { income inequality and not on the } \\
\text { regulatory authority }\end{array}$ \\
\hline
\end{tabular}

ratio, GDP contribution of investment funds' assets, and levels of stock market indices. Barbu et al. (2016) noted linear relationships between SBs and various macroeconomic indicators. Their findings suggest positive relationships between an SB's size and longterm interest rates and stock market indices. However, they observed negative relationships between an SB's size and short-term interest rates, investment fund growth, GDP growth, and M2/GDP ratio. 
Table 7 Key literature on SB and financial stability

\begin{tabular}{|c|c|c|c|c|}
\hline References & Journal/conference & Nature & Country(s)/region & $\begin{array}{l}\text { Main arguments/ } \\
\text { findings }\end{array}$ \\
\hline Barth et al. (2015) & $\begin{array}{l}\text { Journal of Financial } \\
\text { Economic Policy }\end{array}$ & Theoretical & China & $\begin{array}{l}\text { Shadow banks may prove } \\
\text { useful by enhancing } \\
\text { greater savings and } \\
\text { investment opportuni- } \\
\text { ties and diversifying the } \\
\text { Chinese financial sector }\end{array}$ \\
\hline Bengtsson (2013) & $\begin{array}{l}\text { Journal of International } \\
\text { Money and Finance }\end{array}$ & Theoretical & Europe & $\begin{array}{l}\text { Transparency makes it } \\
\text { difficult for European } \\
\text { MMFs investors to } \\
\text { distinguish between } \\
\text { MMFs based on asset } \\
\text { quality. Also, policy } \\
\text { coordination needs } \\
\text { to be improved when } \\
\text { unusual steps are taken } \\
\text { to protect financial } \\
\text { stability }\end{array}$ \\
\hline Bouguelli (2020) & $\begin{array}{l}\text { Journal of Post Keynes- } \\
\text { ian Economics }\end{array}$ & Theoretical & & $\begin{array}{l}\text { As'financial layer- } \\
\text { ing'increases in the } \\
\text { economy alongside } \\
\text { the development of } \\
\text { shadow banking, finan- } \\
\text { cial fragility increases } \\
\text { too. Additionally, as a } \\
\text { large part of shadow } \\
\text { banking is an alterna- } \\
\text { tive source of funds for } \\
\text { banks, financial fragility } \\
\text { increases alongside } \\
\text { the development of } \\
\text { shadow banking }\end{array}$ \\
\hline Culp (2013) & $\begin{array}{l}\text { Journal of Applied } \\
\text { Corporate Finance }\end{array}$ & Theoretical & & $\begin{array}{l}\text { In the leveraged loan } \\
\text { market, bank syndicates } \\
\text { heavily rely on non- } \\
\text { bank investors. There- } \\
\text { fore, the existence and } \\
\text { non-existence of these } \\
\text { investors marginally } \\
\text { affect the banks' ability } \\
\text { to extend C\&l credits }\end{array}$ \\
\hline Culp and Neves (2017) & $\begin{array}{l}\text { Journal of Applied } \\
\text { Corporate Finance }\end{array}$ & Theoretical & United States & $\begin{array}{l}\text { The overall risk exposure } \\
\text { of commercial banks } \\
\text { is being diversified to } \\
\text { the non-bank sector. At } \\
\text { times of liquidity crisis, } \\
\text { shadow banking can } \\
\text { help commercial banks } \\
\text { mitigate their short- } \\
\text { term funding needs }\end{array}$ \\
\hline Liang (2016a) & The Chinese Economy & Theoretical & China & $\begin{array}{l}\text { Although the shadow } \\
\text { banking system in } \\
\text { China is considered a } \\
\text { helpful complement to } \\
\text { the traditional banking } \\
\text { sector, it poses risks to } \\
\text { the wider financial sys- } \\
\text { tem. Therefore, reform } \\
\text { in the financial system } \\
\text { is required as shadow } \\
\text { banking develops }\end{array}$ \\
\hline
\end{tabular}


Table 7 (continued)

\begin{tabular}{|c|c|c|c|c|}
\hline References & Journal/conference & Nature & Country(s)/region & $\begin{array}{l}\text { Main arguments/ } \\
\text { findings }\end{array}$ \\
\hline Tsai (2016) & $\begin{array}{l}\text { The Journal of Develop- } \\
\text { ment Studies }\end{array}$ & Theoretical & China & $\begin{array}{l}\text { China's SMEs suffer from } \\
\text { a financing gap, and } \\
\text { shadow banking keeps } \\
\text { filling it with credit sup- } \\
\text { ply in the market }\end{array}$ \\
\hline Liang (2016b) & $\begin{array}{l}\text { Journal of Economic } \\
\text { Issues }\end{array}$ & Theoretical & China & $\begin{array}{l}\text { Shadow banks engage in } \\
\text { business activities that } \\
\text { increase institutional } \\
\text { risks. Although shadow } \\
\text { banks promote credit- } \\
\text { driven financial growth, } \\
\text { such growth makes the } \\
\text { financial system fragile }\end{array}$ \\
\hline $\begin{array}{l}\text { Diallo and Al-Mansour } \\
\text { (2017) }\end{array}$ & $\begin{array}{l}\text { Research in Interna- } \\
\text { tional Business and } \\
\text { Finance }\end{array}$ & Empirical & (Multiple) & $\begin{array}{l}\text { When the shadow } \\
\text { banking system was } \\
\text { used as a channel, the } \\
\text { insurance sector was } \\
\text { found to be harmful to } \\
\text { the financial stability } \\
\text { of a country where } \\
\text { shadow banking assets } \\
\text { were large }\end{array}$ \\
\hline Landau (2019) & $\begin{array}{l}\text { SEACEN Financial Stabil- } \\
\text { ity Journal }\end{array}$ & Theoretical & & $\begin{array}{l}\text { The development of } \\
\text { shadow banking is } \\
\text { related to the need to } \\
\text { fill a gap in the financial } \\
\text { system. Although } \\
\text { the shadow banking } \\
\text { system is complex, } \\
\text { sophisticated, and } \\
\text { potentially dangerous, } \\
\text { it is also necessary }\end{array}$ \\
\hline $\begin{array}{l}\text { Zhou and Tewari } \\
\text { (2019b) }\end{array}$ & $\begin{array}{l}\text { Cogent Economics \& } \\
\text { Finance }\end{array}$ & Empirical & South Africa & $\begin{array}{l}\text { In South Africa, shadow } \\
\text { banking negatively } \\
\text { affects traditional banks' } \\
\text { profitability. However, } \\
\text { it positively impacts } \\
\text { the profitability of non- } \\
\text { financial firms. Addi- } \\
\text { tionally, it has a positive } \\
\text { impact on aggregate } \\
\text { firm profitability }\end{array}$ \\
\hline Peter Watkins (2011) & $\begin{array}{l}\text { International Journal } \\
\text { of Productivity and } \\
\text { Performance Manage- } \\
\text { ment }\end{array}$ & Theoretical & Canada & $\begin{array}{l}\text { The adoption of shadow } \\
\text { banking has proven } \\
\text { beneficial to the labor } \\
\text { productivity matrix over } \\
\text { a large period }\end{array}$ \\
\hline Zou et al. (2013) & Quality \& Quantity & Empirical & China & $\begin{array}{l}\text { The shadow banking sys- } \\
\text { tem in China develops } \\
\text { the overall financial } \\
\text { system. Nevertheless, } \\
\text { the excessive growth of } \\
\text { shadow banking makes } \\
\text { the economy fragile. } \\
\text { Therefore, the shadow } \\
\text { banking system should } \\
\text { progress slowly and } \\
\text { under the light of the } \\
\text { regulatory body }\end{array}$ \\
\hline
\end{tabular}


Table 7 (continued)

\begin{tabular}{|c|c|c|c|c|}
\hline References & Journal/conference & Nature & Country(s)/region & $\begin{array}{l}\text { Main arguments/ } \\
\text { findings }\end{array}$ \\
\hline $\begin{array}{l}\text { Ilesanmi and Tewari } \\
\text { (2019) }\end{array}$ & $\begin{array}{l}\text { Cogent Economics \& } \\
\text { Finance }\end{array}$ & Theoretical & & $\begin{array}{l}\text { Shadow banking in South } \\
\text { Africa is beneficial as } \\
\text { it provides alternative } \\
\text { sources of credit and } \\
\text { extends investment } \\
\text { opportunities for the } \\
\text { economy. However, a } \\
\text { lack of transparency, } \\
\text { management, and reg- } \\
\text { ulations poses a great } \\
\text { risk to the economy }\end{array}$ \\
\hline
\end{tabular}

Duca (2016) addressed the impact of capital regulation and other factors on the role of SB in funding short-term business debt. Their findings reveal that changes in information and reserve requirement costs and shifts in bank-nonbank credit source regulation had a negative and long-run impact on shadow banks' share in funding short-term business debt. Additionally, their share fell in the short-run when short-run liquidity premia, term premia, and event risks in the security market increased. However, it rose again when the economic outlook improved, risk premia declined, and deposit interest rate ceilings were more binding. Kim (2017) conducted a dynamic panel estimation on G-20 countries to identify factors that drive shadow banking in an economy. He reported that insurance companies and pension funds positively influenced SB growth. Kim (2017) additionally argued that the size of banks' assets had a positive and significant relationship with SB, as suggested by the originate-to-distribute model. Hodula et al. (2017) conducted another study on shadow banking in Spain with SBs' assets as the dependent variable, using the broad measure of SB. Traditional banks' assets, term spread, real GDP, and interest rates (short-term) were independent variables. Hodula et al. (2017) argued that the traditional banking sector's size positively influenced the shadow banking sector's size, and, in most cases, the shadow banking sector reacted pro-cyclically to the development of Spain's real GDP. Hodula et al. (2017) furthermore found that an increase in term spread and low-interest rates positively influenced the growth of the Spanish SB sector. Apostoaie and Bilan (2020) conducted a study on 11 central and eastern European countries, taking both the broad and narrow measures of SB as dependent variables. Independent variables comprised real GDP growth rate, term spread, the growth rate of the total financial assets of pension funds and insurance corporations, money market interest rate, growth rate of the total reserves (excluding gold), and the growth rate of the total assets reported by the Monetary Financial Institutions (as defined by the European Central Bank). Apostoaie and Bilan (2020) found that developments in the traditional banking sector, institutional investors sector, and money market interest rate, overall liquidity and economic conditions influence the SB sector positively. Term spread, however, was found to negatively influence the SB sector. Apostoaie and Bilan (2020) also argued that the development of the SB sector complements the development of the overall financial system. Zhou and Tewari (2019a) investigated SB, bank risk-taking, and monetary policy nexus. They reported a negative relationship between SB and monetary policy. However, they argued that as shadow banking increased, banks 
reduced their risk-taking in the market. Additionally, they reported a positive relationship between SB and GDP and real effective exchange rates and that inflation negatively affected SB growth. The latest study conducted by Hodula et al. (2020) revealed that stiff financial development, strict regulation, and demand for long-term institutional investors positively influenced SB growth. However, they also reported that factors influencing SB growth may function differently in different countries. Other studies reported a "search for yield" effect, i.e., that investors looked for high-yielding assets in the SB sector (e.g., Goda et al. 2013; Lysandrou 2011).

Table 4 presents the main arguments in key literature on determinants of SB.

\section{Shadow banking and systemic risk}

Studies on systemic risk and SB are likewise limited but important enough to merit a stream. Some such studies analyzed SB's overall systemic risk exposure (e.g., Wymeersch 2017; Hsu et al. 2013). Others addressed specific components of SB and the systemic risk exposure that each entailed (e.g., Wei 2015; Bengtsson 2016; Pellegrini et al. 2017).

Bengtsson (2016) analyzed the systemic risk implications of investment funds from a theoretical standpoint. His is the earliest systemic risk study on the role of investment funds in SB. He (2016) distinguished three main systemic risk features on a theoretical basis and considered the possibility of their interconnectedness in real financial system scenarios. He posited that such interconnectedness could increase systemic risk in the credit intermediation process. He further argued that, from the perspective of systemic risk, although hedge funds and conventional investment funds are quite different in terms of business models, they have several commonalities; moreover, investment funds' ability to substitute traditional banks' maturity transformations could be threatened by instability in investment funds' funding profiles. Huang (2018) modeled a continuous-time macro-finance framework where shadow banking is viewed as the offbalance-sheet financing of traditional banks. Huang (2018) suggested that shadow banking is pro-cyclical and that it increases endogenous risks. Pellegrini et al. (2017) studied systemic risk implications of money market funds listed in the UK. Their findings suggest that such funds lowered rather than elevated systemic risk during the GFC. Further, Pellegrini et al. (2017) argued that average systemic risk was increased by liquidity mismatch over the whole study period, but that risk only decreased during the GFC. In contrast, ECB (2020) predicted that in the unprecedented COVID-19 turmoil, the stress in MMFs could spill over to MMF-reliant sectors to manage their liquidity and constrain the financial system and real economy from access to liquidity and short-term funding. However, IOSCO (2020) suggested that MMF category, currency, and strategy differences should be carefully considered when comparing the GFC to the recent stress faced by MMFs.

Tian et al. (2016) empirically investigated systemic risk in China's SB system at the sector level. They included traditional banks, trust companies, securities companies, fund management companies, and insurance companies and found that trust companies were "the main culprit" in China's financial instability. They further found that commercial banks assumed significant risks in the SB system over the 2007-2012 period. In that vein, Tian et al. (2016) found that commercial banks went around regulators' reserve 
deposit ratio and adequacy rate policies by conducting off-balance-sheet transactions, increasing systemic risk in the market. Wei (2015) conducted another study on the Chinese SB system, theorizing the implications of wealth management products on systemic risk. $\mathrm{SB}$, he explained, is considered the black market by regulators and market players. Accordingly, regulators and market players object to its existence on the basis of the financial risks that it generates. However, Wei (2015) argued that such players in the form of commercial banks have enjoyed significant profit generated by wealth management products. He suggested that, accordingly, Chinese policymakers should formulate a multi-tiered market for loans and an interest rate environment based on the market to cure systemic risk in wealth management products.

Hsu et al. (2014) studied the systemic risk implications of banks, securities companies, insurance companies, trust companies, and fund management companies in China on China's SB system. Similar to Tian et al. (2016), they found that trust companies comprise the most significant portion of systemic risk in China's SB sector. Hsu et al. (2014) also found insignificant differences in the systemic risk levels posed by banks, insurance companies, and securities companies in the SB sector. They confirmed Tian et al's (2016) findings that banks absorbed the most systemic risk, about 85\%, in the SB system. Wymeersch's (2017) article on systemic risk and shadow banks theorized that banks were compelled to adapt their behaviors, structures, and balance sheets to the risks of acting in the SB market. Wymeersch (2017) also analyzed several regulations targeting SBs and found that in most such regulations, the motives to protect investors were inexistent. In Hsu et al's (2013) study on SB in Europe and China, several factors, including herd behavior, were found to have created systemic risk in European markets. Furthermore, risk dispersion across the underdeveloped segment of the SB system has led China to some concentrated, localized risks. However, such a segment was not found to contribute to systemic risk (Hsu et al. 2013).

The main arguments found in key literature on SB and systemic risk are presented in Table 5 .

\section{SB politics, policies, and the regulation debate}

Before the GFC, regulators and academics remained unaware of the SB sector to a great extent, highlighting the suitability of the term "Shadow Banking" to refer to it (Helgadóttir 2016). The SB sector does not operate under the safety umbrella of a central bank and comprises many divisions that function independently and, for the most part, lies outside the strict regulations and standard monetary policy that the traditional banking sector is subject to, such as reserve requirements. In 2014, The Economist warned that because it is a large, almost unknown, and fast-growing industry, SB could become "a global bogeyman." They also predicted that although SB could be used as a solid mechanism to avert the next financial crisis, if not managed carefully, it could be of severe detriment to the world economy. There is some tension between that idea and Wallison's (2012) assertion that regulation could cost us this diverse "financial innovation" and leave us with "boring banking," which we saw early on in this review. The political debate among regulators and academics, which addresses the future of SB, including applicable regulations and monetary policies, is an evolving one and one to watch. Accordingly, we turn to SB studies in the fields of law and economics. 
An emerging consonance between academic literature and legislative literature is a vision of SB as the result of regulative arbitration in the traditional banking system enhanced by national accounting, taxation, and banking rules (Nesvetailova 2015). Hachem (2018) argued that stringent liquidity regulations led to the rise of SB in China. As seen above, many have argued that SBs will bring about the next global financial crisis if left unregulated (e.g., Moosa 2017). Wullweber (2020) found that central banks were adapting to this new financial innovation and were in the process of providing ample reserves and access to their balance sheets to SB participants. However, Wullweber (2020) also acknowledged that such policies created contradictions and fragilities and that central banks were searching for other possible ways of dealing with this banking innovation.

Bengtsson (2013) and Plantin (2015) argued that relaxing capital requirements may be optimal if conventional banks can bypass it in the SB system. In a recent study, Irani (2020) concluded that tightening banks' capital regulation gives rise to non-bank presence. They added that when banks with weak capitalization reduce loan exposure, mostly by loan sales, the non-bank sector picks up the slack. Moreover, Zhang (2020) argued that when the extensive-margin effect outweighs the intensive-margin effect, stringent capital requirements will induce rather than curb a credit boom. Zhang (2020) also argued that both total loans and real GDP would be negatively impacted by raising capital requirements if the debt market was segmented and borrowers did not have the option to choose between commercial banks and SBs. Ordonez (2013) proposed combining conventional regulations and cross reputation subsidization to increase sustainability in the SB sector since banks are more concerned for their reputations than SBs. In this regard, Yang et al. (2019) argued that the SB sector is perhaps a strong amplification tool that weakens the implementation of monetary policies and decreases the effectiveness of macroeconomic policies. Further, they added, in times of technological shock, loan-quota shock, and bank's net-worth shock, SB positively influences welfare; conversely, in times of loan-to-deposit ratio shock and monetary policy shock, shadow banking negatively influences welfare. However, Yang et al. (2019) also argued that using look-through regulations to improve financial stability may negatively impact the economy. Therefore, they concluded that coordinating leverage ratio regulations and monetary policies would help stabilize the economy but would also reduce the size of the SB sector. On the other hand, in their study on the Chinese economy, Zhang and Wan (2017) argued that Chinese economic activities should be guided by a mix of policy instruments and that a transition from quantitative policy tools to other price-based instruments would not be easy but would capture monetary policy stances to some extent, especially for open market operations. Nesvetailova (2015) also argued that administrative arbitration approaches to SB are useful but limited considering the scope, diversity, and complexity of SB participants. Wu and Shen (2019) presented evidence suggesting that banks involved in SB activities take more risks than those that are not, but added that good governance could reduce this effect. That being the case, as the macroprudential policies only target traditional banks, and sector leakage reduces their effectiveness, wider regulations addressing shadow credit may help stabilize the economy (Fève et al. 2019). 
Political intervention is yet another piece of the puzzle. Hou et al. (2018) found that political interference weakens managers' ability to efficiently manage financial intermediaries and make optimal production decisions based on market information. Furthermore, evidence from that study suggests that political intervention negatively impacts bank cost efficiency, thus weakening the positive relationship between bank cost efficiency and shadow banking growth. Despite that position, some regulation tools have already been proposed, and others are already being implemented. The Dodd-Frank Act passed in the US in 2010 introduced specific provisions that brought hedge funds, OTC derivatives, retail lenders, and various other institutions important to the SB system under regulation. Gorton and Metrick (2010) argued, however, that the Dodd-Frank act has too many regulatory gaps and proposed the establishment of narrow savings banks and narrow funding banks for regulating reorganization and securitization. Shleifer and Tarullo (2010) argued against Gorton and Metrick (2010), suggesting that their proposal would significantly restrict all ABSs. As policymakers become more concerned with the SB and newer insights into the SB sector emerge, the policy and regulatory debate will surely evolve further, presenting new confluences and conflicts. Table 6 presents the main arguments of the key literature addressing policy and political issues of SB.

\section{$S B$ and financial stability}

This section explores the implications of SB on financial stability and financial development. SB and its implications on financial stability and financial development are of great concern to regulatory authorities. The SB sector was not properly addressed before the GFC, and since then, numerous financial innovations have been taking place within the $\mathrm{SB}$ sector.

In the early 1990s, the "emergence of an unregulated parallel banking system" (SB) was observed by some authors D'Arista and Schlesinger 1993). After the GFC, shadow banking came to the attention of the major regulatory bodies as it was often considered the main culprit in the crisis. Some researchers even argued that the crisis sprouted from the SB sector (Pozsar et al. 2010; Gorton and Metrick 2010; Adrian and Ashcraft 2012; Acharya et al. 2013; Ban and Gabor 2016). Others argued that SB was not entirely to blame for the 2007-2008 sub-prime mortgage crisis and that SBs may be keys to mitigating future liquidity crises in the financial system (e.g., Wallison 2012; Culp 2013; Culp and Neves 2017). Moreover, Wullweber (2020) argued that a stable financial system is currently dependent on a stable SB system.

Shadow banking has recovered quickly since its collapse in 2007-2008, and it outgrew its size (broad measure), capturing an increasing share of the global GDP in 2015, according to FSB (2016). Additionally, the SB sector is increasing rapidly worldwide. Bengtsson (2013) has argued that non-bank financial intermediaries, otherwise known as SBs, and their implications on financial stability must be better understood to alleviate or even avert the next global financial crisis. The growth of SB and the inconclusiveness of the debate on SB prospects make studies addressing its implications on financial stability crucial. Some of the studies addressing such implications focused on specific components of SB (e.g., Culp 2013; Bengtsson 2013), and others addressed the overall SB sector (e.g., Barth et al. 2015; Liang 2016a, Tsai 2016; Zhou and Tewari 2019a, b; Ilesanmi and Tewari 2019). Bengtsson (2013) conducted a study on the European economy 
and reported that there is a lack of transparency regarding the composition of Money Market Fund (MMFs) assets making it difficult for European MMF investors to distinguish between MMFs based on their asset quality. Additionally, Bengtsson (2013) suggested that policy coordination must be improved when unusual measures are taken to protect financial stability. It is noteworthy that several regulatory authorities have already been established to allow for close and effective policy coordination between all relevant agents regularly and during times of crisis. For example, the European Systemic Risk Board was established in 2010 in Europe to prevent and mitigate systemic risk.

Sun (2019) stated that banks' shadow activities increase their credit risk and that they do not adequately assess that risk or take preventive measures. Bouguelli (2020) theorized how shadow banking operates and affects the overall market in the process. Bouguelli (2020) concluded that as "financial layering" increases in the economy alongside the development of shadow banking, financial fragility increases as well. SBs can fatally interrupt financial market equilibrium and inject instability into the financial system that regulators will need to control (Erturk 2017). Furthermore, in the leveraged loan market, bank syndicates rely heavily on non-bank investors, suggesting that whether or not these investors exist marginally affects the banks' ability to extend C\&I credits (Culp 2013). Additionally, as a large part of SB is an alternative source of funds for banks, financial fragility increases alongside the development of SB (Bouguelli 2020). However, the SB system does provide sources for increased loanable funds for commercial banks and assumes some of the risks associated with the loan origination. Therefore, portions of commercial banks' overall risk exposure are being diversified to the nonbanking sector. If the next financial crisis occurs in reverse where traditional banks suffer from a liquidity crisis, SBs can be key in mitigating short-term funding shortages in the financial system (Culp and Neves 2017). Additionally, evidence suggests that money demand functions are becoming more stable with the emergence of SB (Serletis and Xu 2019).

Nevertheless, Huang (2018) presented SB as the off-balance-sheet financing of traditional banks and reported that a limited level of risk-sharing does not improve financial stability. Barth et al. (2015) conducted a study on the Chinese economy and stated that if the Chinese SB system encounters difficulties, such difficulties may also affect China's commercial banks. However, China's regulatory body has developed several policies for governing SB operations and the interconnectedness of SBs and commercial banks. Furthermore, evidence suggests that more municipal, corporate bonds were issued during 2012-2015 in the provinces that saw greater bank loan growth in 2009, along with the development of SB activities (Chen et al. 2020). Additionally, as China's SMEs suffer financing gaps, SB keeps filling these gaps with the supply of credit to the market (Tsai 2016). As such, SBs may prove useful in China by promoting greater and enhanced savings and investment opportunities and diversifying the Chinese financial sector (Tsai 2016, Barth et al. 2015). Additionally, empirical evidence shows that SB positively impacts Chinese economic growth, money supply, and interest rates in the market (Gabrieli et al. 2018).

Zhu (2021) suggested that SB activities induced by conventional banking before 1996 increased efficiency and helped drive credit to more profitable non-state sectors. However, Zhu (2021) reported that the positive effects of SB were limited to real 
estate investments and that the effects on private firms outside this sector were negative. Moreover, Liang (2016a), in his study on China, reported that although the SB sector in China is considered a helpful complement to the Chinese traditional banking sector, it poses risks to the wider financial system.

Loose regulations and SBs' institutional characteristics allow SBs to engage in business activities that increase institutional risk. Although SBs promote credit-driven financial growth, such growth increases the fragility of the financial system (Zou et al. 2013; Liang 2016b). Another study, this one on the South African economy, revealed that SB negatively affected traditional banks' profitability. Furthermore, Ari et al. (2017) argued that the liquidation of SBs could leave traditional banks susceptible to liquidity risk when the SB sector's size is large. However, large size positively impacts the profitability of nonfinancial firms. It was additionally found that the SB sector positively impacts aggregate firm profitability (Zhou and Tewari 2019a, b). Another study argued that SB in South Africa is beneficial as it provides alternative sources of credit and extends economic investment opportunities; yet, lack of transparency, management, and regulations poses great risk to the economy (Ilesanmi and Tewari 2019). In contrast, a study on the Canadian economy suggested that Canada's productivity problem could be solved through innovation. Financial innovation, in this aspect, may come as an SB system. Additionally, the adoption of SB has proven beneficial to Canada's labor productivity matrix over a long period (Watkins 2011). Moreover, Landau (2019) argued that the development of SB relates to the need to fill gaps in the financial system. Therefore, although the SB system is complex, sophisticated, and potentially dangerous, it is also necessary.

Table 7 presents the main arguments made in the key literature on SB and financial stability.

\section{Discussion and future research questions}

The literature on SB is maturing rapidly, and it covers a wide range of research areas. Nonetheless, some aspects of SB remain inconclusive and vastly explorable. Accordingly, we here contribute to the study of SB. We identified seven research questions derived from our exploration of SB literature that should be undertaken in future research to further advance knowledge and understanding of SB.

\section{What drives SB in economies?}

$\mathrm{SB}$ is growing rapidly, both in developed and developing economies. It recovered quickly from its 2007-2008 collapse and outgrew its size (broad measure) in terms of its share of the global GDP in 2015, according to the FSB (2016). However, the forces driving economies towards SB activities are yet to be clearly defined in the literature. The limited number of studies on the topic suggests scope for further exploration of factors leading to the development of SB. As suggested by Apostoaie and Bilan (2020) and Hodula et al. (2017), the impact of regulative arbitrage opportunities on SB could be addressed in this regard. Consistent with Kou et al. (2021a), our study suggests that country-specific analyses can provide essential recommendations for improving the financial systems of particular countries. Simultaneously, we acknowledge that analyses of region interconnectedness can generate interesting findings, as SB participants can be registered in one region and operate in another and can offer financial products to regions on a global scale. That 
being said, we do agree with Hodula et al. (2017) that systematically breaking down and analyzing the different components of SB may present more meaningful and more specific results.

\section{Which components of SB pose the most systemic risk?}

Systemic risk caused by SB is of great concern to regulatory authorities. However, the question of which shadow sector components pose the greater systemic risk to the economy is not addressed thoroughly in the literature. Studies analyzing the systemic risk implications of specific SB components could strengthen our understanding of SB and the risks associated with it. Allen et al.s (2019) findings from a study on entrusted loans in China have several implications for how that component of SB influences the traditional banking sector and the economy at large. Pellegrini et al. (2017) addressed the systematic risks posed by UK MMFs and suggested that analyses of other components of SB, such as finance companies, are likely to yield additional relevant findings in this regard. As An and Yu (2018) stated in their article analyzing off-balance sheet activities in China, the SB sector is highly diversified, and multiple components are largely neglected. Furthermore, the need for studies on the quantification of SB widens the scope for research in this aspect, as different measurement tools reveal different sizes and proportions of components of the SB sector. Moreover, efforts should be made to compile a superior and more comprehensive database. For example, additional detailed breakdowns of investment fund portfolios may allow us to view microscopic components of these shadow entities. Ultimately, SBs' overall systemic risk exposure is yet to be addressed properly in the literature and requires scholarly attention. Indisputably, scholarly contributions can be increased by developing granular and anonymized databases and making them publicly available.

\section{How should SBs be regulated?}

An SB regulation system is another area yet to be properly addressed in the literature. The results of debate among scholars and regulators regarding the existence and regulation of the SB sector are inconclusive. Many scholars suggest that SB participants that do not fall under the regulatory umbrellas and safety nets of central banks should be eradicated (e.g., Bouguelli 2020). Others suggest that the SB sector should be regulated more effectively according to its unique properties so that the benefits of SB can be enjoyed without leading to greater systemic risk in the economy (e.g., Ilesanmi and Tewari 2019). Furthermore, policy coordination should be improved when unusual measures are taken to protect financial stability, as suggested by Bengtsson (2013). More effective supervision of the interconnectedness between the SB sector and the traditional banking sector is also called for to prevent systemic financial layering and ensure the fulfillment of liquidity requirements. Equally importantly, interconnectedness among the different participants in the SB sector should be closely supervised within a macroprudential framework designed to avoid contagion and spillover in both normal times and crises. There is a growing need for studies addressing regulatory reforms and prescriptions, and these will likely be highly appreciated by scholarly and regulatory entities. 


\section{What are the implications of SBs on financial stability?}

Despite accusations of generating financial instability on various occasions, SB is growing rapidly worldwide. The implications of SBs on overall global financial stability remain inconclusive in SB literature. Mixed results and contradictory theories present evidence both in support of and against this sector. All of these can be considered key initiators of research addressing SBs' implications on financial stability. As noted, many argue that SBs increase financial instability in the market by acting as an alternative source of funds for commercial banks and by creating "financial layering" in the market or by interrupting financial market equilibrium (e.g., Erturk 2017; Bouguelli 2020). Łasak et al. (2019) reported that traditional banking and SB are interconnected at three levels (layers): banks' off-balance-sheet financing, indirect support for banks' lending, and non-bank lending. Most post-Keynesians have suggested eliminating or constraining shadow banks to the greatest extent possible. Others have suggested that assuming that another financial crisis will not occur in the traditional banking sector can prove fatal (Landau 2019). In the future, SBs could be key in mitigating liquidity crises in the traditional banking sector (Culp and Neves 2017). Thus, it is important to further research which parts of the SB system, under which types of shocks, can generate financial instability.

\section{How should systemic risk of SB be measured?}

As we have seen, the levels of systemic risk associated with the development of SB activities is another matter of great concern to academics and regulators alike. However, absolute and specific risk measurement tools have not heretofore been developed to measure the systemic risk posed by SBs, and conventional risk measurement tools may not reflect the realities of the SB sector. To that end, Ilesanmi and Tewari (2019) suggested that a unique systemic risk measurement tool be developed for SBs. There appears then to be a growing need for studies suggesting and implementing unique systemic risk measurement tools for SBs.

\section{How does SB development impact traditional banks?}

SBs and traditional banks are highly interconnected in the financial system. Empirical studies and theoretical discussions on how SBs impact traditional banks present contradictory results and remain up for debate among academics. As we have seen, multiple studies argue that the traditional banking sector is under threat from the SB sector and that the SB sector reduces traditional banks' profitability (e.g., Zhou and Tewari 2019a, b; Ding et al. 2020), while others present evidence of a complementary relationship between SBs and traditional banks in the economy (Liang 2016a). SBs provide alternative funding sources for traditional banks and assume some of the risks associated with loan origination. SBs may also provide traditional banks with liquidity support at times (Culp and Neves 2017). As we have seen, traditional banks may move assets off balance sheets, although there is no legitimate reason for them to do so (Tymoigne and Wray 2013), suggesting that the impact of SBs on traditional banking sector requires additional scholarly attention. 


\section{What risks and vulnerabilities does the SB system face?}

As SBs are major players in the world economy, their risks and vulnerabilities can pose risks and introduce vulnerabilities in the greater economy. Moreover, if SBs were to acknowledge the risks and vulnerabilities they face, such a move might likewise disrupt the overall economy. Fang et al. (2020) did address China's entrusted loan market and empirically tested loan risk and collateral in the SB system. However, what kinds of risks SBs may face and what they may be vulnerable to remain to be covered in the literature. Tasky (2019) has done some work in this regard, identifying liquidity risks and risks related to leverage, interconnectedness, and contagion, and to procyclicality, leverage, and liquidity. Tasky (2019) also pointed to significant gaps in data on SBs. Moreover, studies similar to Kou et al. (2021b) should be conducted to develop bankruptcy prediction models for SB entities. Addressing the risks and vulnerabilities of SB entities may bring important and significant findings to this evolving debate.

\section{Conclusion}

Our current endeavor employed a bibliometric tool to trace the evolution and development of SB literature. It identified and presented the most recognized knowledge in the area of SB and attempted to synthesize the key theoretical and empirical findings on SB. VOSviewer, the bibliometric tool employed, is scientific, credible, and has been previously applied in practice by Donthu et al. (2020), Feng et al. (2020), Gutiérrez-Nieto and Serrano-Cinca (2019), Niñerola et al. (2019), to name a few, as noted. Our methods thus reflect the trend in SB research, and our findings can be deemed credibly derived.

After identifying the major papers, sources, and authors in SB literature, content analysis was applied to categorizes the material into four distinct streams, which are discussed in context, with summaries of the key arguments.

However, this study is limited in that the Scopus database was the sole source of the data for bibliometric analysis. Including other databases (e.g., Web of Science, Dimensions) will allow for more thorough mapping of the SB research network. Additionally, more rigorous analyses of individual SB components and addressing interconnectedness among SB entities in different regions will move us toward more finely-tuned insights. We further acknowledge that limiting the data gathered to the results returned from a single search query "shadow banking" may have hindered the presentation of an exhaustive view of the sector, as many articles address the sector without applying the terminology. The research can be expanded in the future by including additional search terms such as "systemic risk," "non-bank financial intermediaries," and "market-based finance." Furthermore, to keep pace with the rapid evolution of SB literature and the SB sector itself, similar studies should be conducted periodically to update the results and continue fine-tuning our understanding.

Growing innovation in the field of finance is contributing to the complexity of the SB sector, and researchers are addressing these newer developments in their studies. Additionally, the COVID-19 pandemic has resurrected some previous concerns about SB. Crisis scenarios can accelerate the growth of SB through firms' increasing demand for alternative sources of financing. Moreover, as the interest rates are predicted to remain low over the next several years, investors will turn to more profitable alternatives, contributing to the growth of assets in the SB sector. In contrast, decreases in 
money circulation in the market induced by the abrupt declines in economic activities due to COVID-19 and related issues can also force the halt of development in the SB sector. Accordingly, much more research is required to understand and broaden our knowledge of SB. Our study model can be extended in the future through the use of multiple databases and different bibliometric tools and by reviewing the SB sector by specific economic region. We further suggest that debates on SB entities' systemic risk exposure and vulnerabilities cannot be concluded until sufficient evidence and additional comprehensive studies are undertaken, and their findings revealed. We suggest that addressing the seven questions presented in the present study in future research questions will move us to a deeper and more accurate understanding of the SB sector and to more informed conclusions on best practices for managing this financial innovation for national and global welfare.

Acknowledgements

Not applicable.

\section{Authors' contributions}

The first author contributed by handling the literature write-up and conducting data analysis. The second author supervises and contributed by writing and editing of the paper. The authors read and approved the final version of the manuscript.

\section{Funding}

The authors hereby declare that there is no form of funding received for this study.

\section{Availability of data and materials}

Data used in this paper were collected from Scopus database.

\section{Declarations}

\section{Competing interest}

The authors declare that they have no competing interests.

Received: 16 April 2020 Accepted: 18 August 2021

Published online: 01 October 2021

\section{References}

Acharya W, Khandwala H, Öncü TS (2013) The growth of a shadow banking system in emerging markets: evidence from India. J Int Money Financ 39:207-230. https://doi.org/10.1016/j.jimonfin.2013.06.024

Adrian T, Shin HS (2010) The changing nature of financial intermediation and the financial crisis of 2007-2009. Ann Rev Econ 2(1):603-618. https://doi.org/10.1146/annurev.economics.102308.124420

Ağırman E, Serçemeli M, Özcan M (2013) Shadow banking: an overview. In: 9th Iberian international business conference, Braga-Portugal. http://www3.eeg.uminho.pt/economia/nipe/iibc2013/6.3.pdf

Allen F, Qian Y, Tu G, Yu F (2019) Entrusted loans: a close look at China's shadow banking system. J Financ Econ 133(1):1841. https://doi.org/10.1016/j.jfineco.2019.01.006

An P, Yu M (2018) Neglected part of shadow banking in China. Int Rev Econ Financ 57:211-236. https://doi.org/10.1016/j. iref.2018.01.005

Apostoaie CM, Bilan I (2020) Macro determinants of shadow banking in Central and Eastern European countries. Econ Res Ekonomska Istraživanja 33(1):1146-1171. https://doi.org/10.1080/1331677x.2019.1633943

Ari, M. A., Darracq-Paries, M., Kok, C., \& Zochowski, D. (2017). Shadow banking and market discipline on traditional banks. IMF Working Papers. https://doi.org/10.5089/9781484335376.001

Ashcraft AB, Adrian T (2012) Shadow banking: a review of the literature. Federal Reserve Bank of New York Staff Reports (No. 580). https://www.newyorkfed.org/medialibrary/media/research/staff_reports/sr580.pdf

Awrey D (2015) Law and finance in the Chinese shadow banking system. Cornell Int Law J 48(1):1-49. https://doi.org/10. 2139/ssin.2381171

Bahoo S, Alon I, Paltrinieri A (2020a) Corruption in international business: a review and research agenda. Int Bus Rev 29(4):101660. https://doi.org/10.1016/j.ibusrev.2019.101660

Bahoo S, Alon I, Paltrinieri A (2020b) Sovereign wealth funds: past, present, and future. Int Rev Financ Anal 67:101418. https://doi.org/10.1016/j.irfa.2019.101418

Ban C, Gabor D (2016) The political economy of shadow banking. Rev Int Polit Econ 23(6):901-914. https://doi.org/10 1080/09692290.2016.1264442

Ban C, Seabrooke L, Freitas S (2016) Grey matter in shadow banking: international organizations and expert strategies in global financial governance. Rev Int Polit Econ 23(6):1001-1033. https://doi.org/10.1080/09692290.2016.1235599 
Barbu TC, Boitan IA, Cioaca SI (2016) Macroeconomic determinants of shadow banking-evidence from EU countries. Rev Econ Bus Stud 9(2):111-129. https://doi.org/10.1515/rebs-2016-0037

Barth JR, Li T, Shi W, Xu P (2015) China's shadow banking sector: beneficial or harmful to economic growth? J Finan Econ Policy 7(4):421-445. https://doi.org/10.1108/jfep-07-2015-0043

Bengtsson E (2013) Shadow banking and financial stability: European money market funds in the global financial crisis. J Int Money Financ 32:579-594. https://doi.org/10.1016/j.jimonfin.2012.05.027

Bengtsson E (2016) Investment funds, shadow banking, and systemic risk. J Financ Regul Compliance 24(1):60-73. https://doi.org/10.1108/jfrc-12-2014-0051

Bouguelli R (2020) Is shadow banking really akin to banking? A critical analysis in light of monetary theory. J Post Keynes Econ 43(1):1-27. https://doi.org/10.1080/01603477.2019.1684826

Castillo-Vergara M, Alvarez-Marin A, Placencio-Hidalgo D (2018) A bibliometric analysis of creativity in the field of business economics. J Bus Res 85:1-9. https://doi.org/10.1016/j.jbusres.2017.12.011

Chadegani AA, Salehi H, Yunus MM, Farhadi H, Fooladi M, Farhadi M, Ebrahim NA (2013) A comparison between two main academic literature collections: web of Science and Scopus databases. Asian Soc Sci 9(5):18-26. https://doi. org/10.5539/ass.v9n5p18

Chen K, Ren J, Zha T (2018) The nexus of monetary policy and shadow banking in China. Am Econ Rev 108(12):38913936. https://doi.org/10.1257/aer.20170133

Chen Z, He Z, Liu C (2020) The financing of local government in China: Stimulus loan wanes and shadow banking waxes. J Financ Econ 137(1):42-71. https://doi.org/10.1016/j.jfineco.2019.07.009

Chernenko S, Sunderam A (2014) Frictions in shadow banking: evidence from the lending behavior of money market mutual funds. Rev Financ Stud 27(6):1717-1750. https://doi.org/10.1093/rfs/hhu025

Culp CL (2013) Syndicated leveraged loans during and after the crisis and the role of the shadow banking system. J Appl Corp Financ 25(2):63-85. https://doi.org/10.1111/jacf.12016

Culp CL, Neves AM (2017) Shadow banking, risk transfer, and financial stability. J Appl Corp Financ 29(4):45-64. https:// doi.org/10.1111/jacf.12261

D’Arista J, Schlesinger T (1993) The parallel banking system. Economic Policy Institute. https://citeseerx.ist.psu.edu/viewd oc/download?doi=10.1.1.590.2468\&rep=rep1\&type $=$ pdf

Diallo B, Al-Mansour A (2017) Shadow banking, insurance, and financial sector stability. Res Int Bus Financ 42:224-232. https://doi.org/10.1016/j.ribaf.2017.04.024

Ding N, Fung HG, Jia J (2020) Shadow banking, bank ownership, and bank efficiency in China. Emerg Mark Financ Trade 56(15):3785-3804. https://doi.org/10.1080/1540496x.2019.1579710

Donthu N, Kumar S, Pattnaik D (2020) Forty-five years of journal of business research: a bibliometric analysis. J Bus Res 109:1-14. https://doi.org/10.1016/j.jbusres.2019.10.039

Duca JV (2016) How capital regulation and other factors drive the role of shadow banking in funding short-term business credit. J Bank Financ 69:S10-S24. https://doi.org/10.1016/j.jbankfin.2015.06.016

ECB (2020) Financial stability review: recent stress in money market funds has exposed potential risks for the wider financial system. European Central Bank. https://www.ecb.europa.eu/pub/financial-stability/fsr/focus/2020/html/ ecb.fsrbox202005_07 725c8a7ec8.en.html

The Economist (2014) The lure of shadow banking. https://www.economist.com/leaders/2014/05/08/the-lure-ofshadow-banking

Erturk I (2017) Shadow banking: a story of the Doppelgänger (the Double) in science of finance. J Cult Econ 10(4):377392. https://doi.org/10.1080/17530350.2016.1251955

Fang S, Qian X, Zou W (2020) The empirical relation between loan risk and collateral in the shadow banking system: evidence from China's entrusted loan market. Int Rev Econ Financ 67:42-54. https://doi.org/10.1016/j.iref.2019.12.012

Feng CM, Park A, Pitt L, Kietzmann J, Northey G (2020) Artificial intelligence in marketing: a bibliographic perspective. Australas Mark J (AMJ). https://doi.org/10.1016/j.ausmj.2020.07.006

Fève P, Moura A, Pierrard O (2019) Shadow banking and financial regulation: a small-scale DSGE perspective. J Econ Dyn Control 101:130-144. https://doi.org/10.1016/j.jedc.2019.02.001

FSB (2011a) Shadow banking: strengthening oversight and regulation. Financial Stability Board. https://www.fsb.org/wpcontent/uploads/r_111027a.pdf?page_moved $=1$

FSB (2011 b) Shadow banking: scoping the issues. Financial Stability Board. https://www.fsb.org/wp-content/uploads/r_ 110412a.pdf

FSB (2012) Global shadow banking monitoring report 2012. Financial Stability Board. https://www.fsb.org/wp-content/ uploads/r_121118c.pdf

FSB (2016) Global shadow banking monitoring report 2016. Financial Stability Board. https://www.fsb.org/wp-content/ uploads/global-shadow-banking-monitoring-report-2016.pdf

FSB (2019) Global monitoring report on non-bank financial intermediation 2018. Financial Stability Board. https://www. fsb.org/wp-content/uploads/P040219.pdf

FSB (2020) Global monitoring report on non-bank financial intermediation 2020. Financial Stability Board. https://www. fsb.org/wp-content/uploads/P161220.pdf

Gabor D (2016) A step too far? The European financial transactions tax on shadow banking. J Eur Public Policy 23(6):925945. https://doi.org/10.1080/13501763.2015.1070894

Gabrieli T, Pilbeam K, Shi B (2018) The impact of shadow banking on the implementation of Chinese monetary policy. Int Econ Econ Policy 15(2):429-447. https://doi.org/10.1007/s10368-017-0397-z

Geithner T (2008) Reducing systemic risk in a dynamic financial system. Federal Reserve Bank of New York, 15. https:// www.bis.org/review/r080612b.pdf

Gennaioli N, Shleifer A, Vishny RW (2013) A model of shadow banking. J Financ 68(4):1331-1363. https://doi.org/10.1111/ jofi.12031

Goda T, Lysandrou P, Stewart C (2013) The contribution of US bond demand to the US bond yield conundrum of 2004-2007: an empirical investigation. J Int Financ Mark Inst Money 27:113-136. https://doi.org/10.1016/j.intfin. 2013.07.012 
Gorton G, Metrick A (2010) Regulating the shadow banking system. In: Brookings papers on economic activity, pp 261-297. https://doi.org/10.1353/eca.2010.0016

Gutiérrez-Nieto B, Serrano-Cinca C (2019) 20 years of research in microfinance: an information management approach. Int J Inf Manag 47:183-197. https://doi.org/10.1016/j.ijinfomgt.2019.01.001

Hachem K (2018) Shadow banking in China. Ann Rev Financ Econ 10:287-308. https://doi.org/10.1146/annurev-finan cial-110217-023025

Helgadóttir O (2016) Banking upside down: the implicit politics of shadow banking expertise. Rev Int Polit Econ 23(6):915-940. https://doi.org/10.1080/09692290.2016.1224196

Hodula M, Melecky A, Machacek M (2020) Off the radar: factors behind the growth of shadow banking in Europe. Econ Syst 44(3):100808. https://doi.org/10.1016/j.ecosys.2020.100808

Hodula M, Machacek M, Melecky A (2017) Macroeconomic determinants of shadow banking: evidence from Spain. In: European financial systems 2017, Proceedings of the 14th international scientific conference, vol 1, pp 204-212

Hou X, Li S, Guo P, Wang Q (2018) The cost effects of shadow banking activities and political intervention: evidence from the banking sector in China. Int Rev Econ Financ 57:307-318. https://doi.org/10.1016/j.iref.2018.01.019

Hsu S, Li J, Qin Y (2013) Shadow banking and systemic risk in Europe and China. SSRN Electron J. https://doi.org/10.2139/ ssin. 2215233

Hsu S, Li J, Xue Y (2014) Shadow banking and systemic risk in China. Political economy research institute working paper, $p$ 349. https://www.peri.umass.edu/fileadmin/pdf/working_papers/working_papers_301-350/WP349.pdf

Huang J (2018) Banking and shadow banking. J Econ Theor 178:124-152. https://doi.org/10.1016/j.jet.2018.09.003

Iddy JJ, Alon I (2019) Knowledge management in franchising: a research agenda. J Knowl Manag 23(4):763-785. https:// doi.org/10.1108/jkm-07-2018-0441

Ilesanmi KD, Tewari DD (2019) Management of shadow banks for economic and financial stability in South Africa. Cogent Econ Financ 7(1):1568849. https://doi.org/10.1080/23322039.2019.1568849

IOSCO (2020) Money Market Funds during the March-April Episode. The International Organization of Securities Commissions. https://www.iosco.org/library/pubdocs/pdf/IOSCOPD666.pdf

Kim S (2017) What drives shadow banking? A dynamic panel evidence. IFC Bulletins chapters. In: Bank for International Settlements (ed) Statistical implications of the new financial landscape (43). https://www.bis.org/ifc/publ/ifcb43_ i.pdf

Kodres LE (2013) What is shadow banking? Financ Dev 50(2):42-43

Kou G, Akdeniz ÖO, Dinçer H, Yüksel S (2021a) Fintech investments in European banks: a hybrid IT2 fuzzy multidimensional decision-making approach. Financ Innov 7(1):1-28. https://doi.org/10.1186/s40854-021-00256-y

Kou G, Xu Y, Peng Y, Shen F, Chen Y, Chang K, Kou S (2021 b) Bankruptcy prediction for SMEs using transactional data and two-stage multiobjective feature selection. Decis Support Syst 140:113429. https://doi.org/10.1016/..dss.2020. 113429

Landau JP (2019) Shadow banking and financial stability. SEACEN Financ Stab J (1). https://www.seacen.org/publicatio ns/RePEc/702001-100453-PDF.pdf

Łasak P, Szyszko A, Pagacz P (2019) The interconnectedness between traditional banks, shadow banking, and non-performing loans in the Chinese economy. Bank Credit 50(4):347-374

LiT (2014) Shadow banking in China: expanding scale, evolving structure. J Financ Econ Policy 6(3):198-211. https://doi. org/10.1108/jfep-11-2013-0061

Liang Y (2016a) Shadow banking in China: implications for financial stability and macroeconomic rebalancing. Chin Econ 49(3):148-160. https://doi.org/10.1080/10971475.2016.1159903

Liang Y (2016) Inside shadow banking in China: credit-driven growth vs. financial stability. J Econ Issues 50(2):461-470. https://doi.org/10.1080/00213624.2016.1179046

Lu Y, Guo H, Kao EH, Fung HG (2015) Shadow banking and firm financing in China. Int Rev Econ Financ 36:40-53. https:// doi.org/10.1016/j.iref.2014.11.006

Lysandrou P (2011) The primacy of hedge funds in the subprime crisis. J Post Keynesian Econ 34(2):225-254. https://doi. org/10.2753/pke0160-3477340203

Lysandrou P, Nesvetailova A (2015) The role of shadow banking entities in the financial crisis: a disaggregated view. Rev Int Polit Econ 22(2):257-279. https://doi.org/10.1080/09692290.2014.896269

McCulley P (2007) Teton reflections. PIMCO Global Central Bank Focus, 2. http://media.pimco-global.com/pdfs/pdf_sg/ GCB\%20Focus\%20Sept\%2007\%20SGP-HK.pdf

Meeks R, Nelson B, Alessandri P (2017) Shadow banks and macroeconomic instability. J Money Credit Bank 49(7):14831516. https://doi.org/10.1111/jmcb.12422

Moosa IA (2017) The regulation of shadow banking. J Bank Regul 18(1):61-79. https://doi.org/10.1057/jbr.2015.8

Moreira A, Savov A (2017) The macroeconomics of shadow banking. J Financ 72(6):2381-2432. https://doi.org/10.1111/ jofi. 12540

Naatu F, Alon I (2019) Social franchising: a bibliometric and theoretical review. J Promot Manag 25(5):738-764. https://doi. org/10.1080/10496491.2019.1584777

Nesvetailova A (2015) A crisis of the overcrowded future: shadow banking and the political economy of financial innovation. New Polit Econ 20(3):431-453. https://doi.org/10.1080/13563467.2014.951428

Niñerola A, Sánchez-Rebull MV, Hernández-Lara AB (2019) Tourism research on sustainability: a bibliometric analysis. Sustainability 11(5):1377. https://doi.org/10.3390/su1 1051377

Noeth BJ, Sengupta R (2011) Is shadow banking really banking? Reg Econ 10:8-13

Ordonez G (2013) Sustainable shadow banking. National Bureau of Economic Research (No. 19022). https://doi.org/10. $3386 / \mathrm{w} 19022$

Paul J, Benito GR (2018) A review of research on outward foreign direct investment from emerging countries, including China: what do we know, how do we know, and where should we be heading? Asia Pac Bus Rev 24(1):90-115. https://doi.org/10.1080/13602381.2017.1357316

Paul J, Rosado-Serrano A (2019) Gradual internationalization vs. Born-Global/International new venture models. Int Mark Rev 36(6):830-858. https://doi.org/10.1108/imr-10-2018-0280 
Paul J, Singh G (2017) The 45 years of foreign direct investment research: approaches, advances, and analytical areas. World Econ 40(11):2512-2527. https://doi.org/10.1111/twec.12502

Pellegrini CB, Meoli M, Urga G (2017) Money market funds, shadow banking, and systemic risk in the United Kingdom. Financ Res Lett 21:163-171. https://doi.org/10.1016/j.frl.2017.02.002

Plantin G (2015) Shadow banking and bank capital regulation. Rev Financ Stud 28(1):146-175. https://doi.org/10.1093/ rfs/hhu055

Pozsar Z, Adrian T, Ashcraft AB, Boesky H (2010) Shadow banking. SSRN Electron J. https://doi.org/10.2139/ssrn.1645337

Pozsar Z (2018) Shadow banking: a view from the USA. In: Shadow banking: scope, origins and theories. Routledge, pp 19-24. https://www.routledge.com/Shadow-Banking-Scope-Origins-and-Theories/Nesvetailova/p/book/97803 67140373\#

Rixen T (2013) Why reregulation after the crisis is feeble: shadow banking, offshore financial centers, and jurisdictional competition. Regul Gov 7(4):435-459. https://doi.org/10.1111/rego.12024

Serletis A, Xu L (2019) The demand for banking and shadow banking services. N Am J Econom Financ 47:132-146. https://doi.org/10.1016/j.najef.2018.12.009

Shleifer A, Tarullo DK (2010) Comments and discussion. Brookings papers on economic activity, pp 298-312. https://doi. org/10.1353/eca.2010.0021

Stein JC (2010) Securitization, shadow banking \& financial fragility. Daedalus 139(4):41-51. https://doi.org/10.1162/ daed_a_00041

Sun G (2019) China's shadow banking: bank's shadow and traditional shadow banking. BIS working papers (No. 822). https://www.bis.org/publ/work822.pdf

Sunderam A (2015) Money creation and the shadow banking system. Rev Financ Stud 28(4):939-977. https://doi.org/10. 1093/rfs/hhu083

Tian G, Li J, Xue Y, Hsu S (2016) Systemic risk in the Chinese shadow banking system: a sector-level perspective. Emerg Mark Financ Trade 52(2):475-486. https://doi.org/10.1080/1540496x.2016.1110465

Tymoigne E, Wray LR (2013) The rise and fall of money manager capitalism: Minsky's half-century from World War two to the great recessionhttps://doi.org/10.4324/9780203717295

Van Eck NJ, Waltman L (2010) Software survey: VOSviewer, a computer program for bibliometric mapping. Scientometrics 84(2):523-538. https://doi.org/10.1007/s11192-009-0146-3

Van Eck NJ, Waltman L (2014) Visualizing bibliometric networks. Meas Sch Impact. https://doi.org/10.1007/978-3-31910377-8_13

Wallison PJ (2012) Does shadow banking require regulation? American Enterprise Institute for Public Policy Research (No. 34648). https://www.aei.org/research-products/report/does-shadow-banking-require-regulation/

Watkins P (2011) Shadow banking: accounting for Canada's productivity gap. Int J Prod Perform Manag 60(8):857-864. https://doi.org/10.1108/17410401111182233

Wei S (2015) Wealth management products in the context of China's shadow banking: systemic risks, consumer protection and regulatory instruments. Asia Pac Law Rev 23(1):91-123. https://doi.org/10.1080/10192557.2015.11745931

White GO, Guldiken O, Hemphill TA, He W, Khoobdeh MS (2016) Trends in international strategic management research from 2000 to 2013: text mining and bibliometric analyses. Manag Int Rev 56(1):35-65. https://doi.org/10.1007/ s11575-015-0260-9

Wu MW, Shen CH (2019) Effects of shadow banking on bank risks from the view of capital adequacy. Int Rev Econ Financ 63:176-197. https://doi.org/10.1016/j.iref.2018.09.004

Wullweber J (2020) Embedded finance: the shadow banking system, sovereign power, and new state-market hybridity. J Cult Econ 13(5):592-609. https://doi.org/10.1080/17530350.2020.1741015

Wymeersch E (2017) Shadow banking and systemic risk. Eur Econ Macroecon Monet Econ eJ. https://doi.org/10.2139/ ssrn.2912161

Yang L, van Wijnbergen S, Qi X, Yi Y (2019) Chinese shadow banking, financial regulation, and effectiveness of the monetary policy. Pac Basin Financ J 57:101169. https://doi.org/10.1016/j.pacfin.2019.06.016

Zha Q, Kou G, Zhang H, Liang H, Chen X, Li CC, Dong Y (2020) Opinion dynamics in finance and business: a literature review and research opportunities. Financ Innov 6(1):1-22. https://doi.org/10.1186/s40854-020-00211-3

Zhang J (2020) Shadow banking and optimal capital requirements. Rev Econ Dyn 38:296-325. https://doi.org/10.1016/j. red.2020.05.004

Zhang S, Wan J (2017) Do China's shadow banking interest rates capture its monetary policy stance? Emerg Mark Finance Trade 53(12):2686-2695. https://doi.org/10.1080/1540496x.2017.1377067

Zhang D, Xu J, Zhang Y, Wang J, He S, Zhou X (2020) Study on sustainable urbanization literature based on Web of Science, Scopus, and China national knowledge infrastructure: a scientometric analysis in CiteSpace. J Clean Prod 264:121537. https://doi.org/10.1016/j.jclepro.2020.121537

Zhou S, Tewari DD (2019a) Shadow banking, risk-taking and monetary policy in emerging economies: a panel cointegration approach. Cogent Econ Financ 7(1):1636508. https://doi.org/10.1080/23322039.2019.1636508

Zhou S, Tewari DD (2019b) Shadow financial services and firm performance in South Africa. Cogent Econ Financ 7(1):1603654. https://doi.org/10.1080/23322039.2019.1603654

Zhu X (2021) The varying shadow of China's banking system. J Comp Econ 49(1):135-146. https://doi.org/10.1016/j.jce. 2020.07.006

Zou XP, Pang YX, Zhu HL (2013) The study between shadow banking and financial fragility in China: an empirical analysis based on the co-integration test and error correction model. Qual Quant 47(6):3363-3370. https://doi.org/10. 1007/s11135-012-9725-0

\section{Publisher's Note}

Springer Nature remains neutral with regard to jurisdictional claims in published maps and institutional affiliations. 